\title{
The Impact of Restricting Labor Mobility on Corporate Investment and Entrepreneurship
}

\author{
Jessica S. Jeffers* \\ May 7, 2018
}

\begin{abstract}
I investigate the impact of restricting labor mobility on two components of growth: entrepreneurship and capital investment. To identify the mechanism, I combine LinkedIn's database of employment histories with staggered changes in the enforceability of noncompete agreements, mostly from court rulings. Stronger enforceability leads to a substantial decline in employee departures, especially in knowledge-intensive occupations, and reduces entrepreneurship in corresponding sectors. However, these shocks increase the investment rate at existing knowledge-intensive firms. The estimates in my sample suggest that, in such sectors, there is roughly $\$ 1.8$ million of additional capital investment from publicly-held firms for every lost new firm entry.
\end{abstract}

\footnotetext{
*University of Chicago, Booth School of Business. jessica.jeffers@chicagobooth.edu. I am grateful to David Musto, Erik Gilje, Todd Gormley, and Michael Roberts for their guidance. I also thank Ian Appel, Tony Cookson, Anna Cororaton, Olivier Darmouni, Amora Elsaify, Deeksha Gupta, Michael Lee, David Matsa, Adrien Matray, Devin Reilly, attendees at the Colorado Finance Summit, the Kauffman Entrepreneurship Scholars Conference, the MFA and Manchester Conference, and seminar participants at Wharton (including MIDAs), CMU, Booth, Vanderbilt, the FRB, Columbia, HBS, Berkeley, U. Minnesota, UBC, USC, Imperial, Rice, Georgetown, UCLA, Stern, Stanford, Kellogg, LSE, Nova, SFI, TSE, Duke, and MIT. The Ewing Marion Kauffman Foundation provided support for this research through the Kauffman Dissertation Fellowship program. This project was made possible by LinkedIn through its 2015 Economic Graph Challenge, and I wish to thank Christine Baxter, Guy Berger, Lutz Finger, Natalie Han, Kevin Morsony and Jason Schissel for making this possible.
} 


\section{Introduction}

Recent research and policy proposals have renewed the debate over agreements that prevent workers from leaving their employers ("labor mobility restrictions") (White House Report 2016). On the one hand, limiting mobility can dampen innovation and regional growth (Saxenian 1994, Gilson 1999). On the other hand, limiting mobility may have a positive impact on existing firms. In particular, an ex-ante agreement for the employee not to leave the employer may foster growth by safeguarding the employer's investment, especially where search frictions or learning on the job make it difficult to replace human capital (Acemoglu and Shimer 1999, Zingales 2000).

Thus mobility, in theory, trades the benefit of reallocating labor to more productive ventures against the cost of dampening investment at existing firms. The objective of this paper is to empirically document and quantify this bidirectional effect. Specifically, I estimate the impact of restricting labor mobility on two ways of exploiting growth opportunities: entrepreneurship, and capital investment. These outcomes are of particular interest for two reasons. First, new firm entry is a key ingredient of economic growth, yet the startup rate of new businesses has declined in recent decades, including in high-tech sectors (Decker, Haltiwanger, Jarmin and Miranda 2014). Second, business investment is an important source of productivity growth and has been uneven since the crisis (Furman 2015). Studying the impact of labor mobility restrictions is important because it can help shed some light on these trends. Moreover, these two components of growth intuitively trade off: it is a tension underlying both the concepts of creative destruction (Schumpeter 1942) and boundaries of the firm (Coase 1937).

Examining the above trade-off presents two key empirical challenges. First, it requires a strategy to address the potential endogeneity of mobility with respect to economic outcomes. Since randomly assigning mobility restrictions to employees is not 
possible, this means finding a source of variation in labor mobility that is otherwise uncorrelated with capital investment and entrepreneurship. The second challenge is observing mobility for a large and diverse set of workers, including information on their employment before and after moving, and the entry of new firms that capture growth (as opposed to subsistence) entrepreneurship.

To address the first challenge, I focus on a particular restriction on labor mobility, non-compete agreements (NCs). NCs are contract provisions that preclude employees from moving to, or establishing, a competitor for a period of time after leaving their employer. I rely on state-level variation in the enforceability of these contracts to tackle the endogeneity concern. Specifically, my identification strategy relies on a new setting of seven state supreme court rulings and one law that modified the enforceability of NCs between 2008 and 2014. Court rulings provide a particularly useful empirical setting because courts are not subject to lobbying and other pressures in the same way as legislators are. Indeed, I find no evidence that the changes are anticipated or otherwise systematically associated with different types of workers, firms, or political and economic environments in a way that would bias the results. NCs also provide a valuable setting for studying this question because they affect mobility for a large number of workers: Starr, Prescott and Bishara (2018) estimate that $18 \%$ of all labor force participants are currently subject to a NC, with rates as high as $35 \%$ among tech workers and engineers.

For the second challenge, measuring labor mobility, I also use a novel data source: the detailed de-identified employment histories of LinkedIn members ${ }^{1}$ A key advantage of these data is the presence of standardized position-level information such as occupation and seniority. This allows me to focus on workers and firms for which NCs matter

\footnotetext{
${ }^{1}$ In 2015, LinkedIn awarded access to its database to a small number of researchers selected through a competitive process called the Economic Graph Challenge. The data contain no name information and numerical member identifiers in the data were hashed.
} 
the most, namely those engaged in and relying on knowledge-intensive activities (Starr et al. 2018). Moreover, I observe company-level information such as industry and year founded for both origin and destination firms. As a result I am able to isolate moves to competitors and to new businesses, and the entry of new businesses. Importantly, the type of new firm that I will capture on LinkedIn is more likely to be the kind of growth entrepreneurship that is of interest here, as opposed to new establishments or new subsistence entrepreneurship that census-type data capture. Another important advantage is that the data encompass a wide range of workers in all fifty states. Looking at active LinkedIn members, I observe employment paths for 52 million workers in the U.S., or roughly one-third of the U.S. workforce.

The paper contains three main results. First, I establish the internal validity of my approach by verifying that NC enforcement has a significant impact on labor mobility. In my setting, an increase in $\mathrm{NC}$ enforceability leads to a 0.7 percentage point drop in the total departure rate. This drop is economically large, representing $8 \%$ of the average departure rate. For workers in knowledge-intensive occupations, I estimate a $17 \%$ decrease in the average departure rate. Consistent with the language in NC agreements, declines are particularly pronounced for within-industry departures, and for departures to positions of greater or equal seniority to the position the employee is leaving, which are most likely to be voluntary departures and moves that build on experience. I further focus on a subsample of knowledge-intensive occupations ("knowledge workers"), which survey evidence suggests are most prone to NC restrictions (Starr et al. 2018) ${ }^{2}$ The idea is that, because of the knowledge involved in their occupations, the mobility of these workers is more costly to firms. I find that it is these knowledge workers in particular who drive the departure impact of NC enforceability.

\footnotetext{
${ }^{2}$ Knowledge worker occupations are defined in section 4.2 and include: arts \& design, business development, consulting, education, engineering, entrepreneurship, finance, information technology, media \& communication, operations, product management, program \& project management, and research.
} 
Next, I estimate the economic impact of these changes in labor mobility by considering two sets of outcomes: new firm entry and capital investment. I measure departures to new firms by counting departures to businesses founded within a year of the employee's departure, and find evidence that knowledge workers are less likely to join or start new firms following an increase in the enforceability of NCs. In turn, the entry of new firms in knowledge sectors declines by $18 \%$ relative to average 3

Lastly, I examine the impact of NC enforceability on capital investment. Entrepreneurship declines when NCs are more enforceable, yet it is possible there is an economic benefit for existing firms. In particular, if human capital is hard to replace and its relationship with physical capital is complementary - for example, expensive computers are worth acquiring if the firm can retain talented programmers - then tighter restrictions on labor mobility will increase the rate of capital investment. Consistent with this hypothesis, I find that in firms that are more highly dependent on human capital, the net capital investment rate rises. Knowledge-intensive firms increase investment by $\$ 8$-10k for every $\$ 100 \mathrm{k}$ of capital, or roughly $\$ 22$-24 million for the average firm and $\$ 3$ million for the median firm.

Finally, I do a back-of-the-envelope calculation to understand the trade-off these estimates imply between increased capital investment on the one hand, and decreased firm entry on the other. The estimates for my sample suggest about $\$ 1.8$ million of capital investment from publicly-held knowledge-intensive firms is added for every lost new knowledge-intensive firm entry.

The results stand up to a range of robustness analyses. An important assumption underlying the empirical approach is that treated and untreated observations are trending similarly before the change in NC enforceability, and would have continued to do so

\footnotetext{
${ }^{3}$ Knowledge sectors are: Technology; Professional, scientific \& technical services; and Education \& training.
} 
absent the change. I show graphically that when I break out the difference estimates by years to and from treatment, the estimates are close to zero and fairly stable prior to the NC changes, and the effects occur after the NC changes. Throughout, I include industry-year fixed effects to account for industry conditions year to year, and firm fixed effects to allow for different firm-specific baselines whenever applicable. Results are also robust to including firm-year or state-year fixed effects whenever possible (e.g., in triple difference specifications). This addresses concerns that unobserved local conditions could drive both court rulings and mobility and investment outcomes. Finally, I test robustness to different levels of "employee concentration" for firms: To assign the law changes to firms, I use the state in which a firm has the most employees as that firm's state of assignment; I show that the greater the fraction of a firm's employees who are in this state of assignment (i.e., the less noisy is the treatment assignment), the more significant the results are, both statistically and economically.

The main contribution of this paper is to document a trade-off between entrepreneurship and capital investment as a result of tighter mobility restrictions, and to provide more granular and broad-based evidence for the mechanism than previously possible. As such, the paper fits in with three related but distinct sets of literature. First, this paper builds on questions raised by Zingales (2000) about corporate finance in the context of firms' increasing dependence on human capital, and picked up in a growing literature relating frictions in human capital to firm value (Chen, Kacperczyk and OrtizMolina 2011, Eiling 2013, Donangelo 2014). More specific to my context, a few studies relate these frictions to capital decisions (Autor, Kerr and Kugler 2007, Garmaise 2011). Garmaise (2011), in particular, also considers the role of NCs, though the paper focuses on CEOs rather than rank-and-file knowledge workers, and finds that investment relative to labor decreases after NCs become more enforceable in three states. In contrast, I find in my setting that investment increases with $\mathrm{NC}$ enforcement, and argue that 
this is due to complementarities between human and physical capital in knowledgeintensive firms 4 At the same time, I find that there is a substantial trade-off between this investment increase and new firm entry. In the context of theory of the firm, these findings support the argument that control rights over human capital are a critical component of firm boundaries, in the sense that they help determine whether investment opportunities are exploited within existing firms (manifesting as capital investment) or as new ventures (new firm entry) (Zingales 2000).

Second, this paper contributes to the growing literature on labor mobility restrictions. Other papers studying the relationship between NCs and employee departures include Marx, Strumsky and Fleming (2009) (inventors), Garmaise (2011) (executives), Lavetti, Simon and White (2014) (physicians), and Starr et al. (2018) (survey) $\bigsqcup^{5}$ Conti (2014) also considers the impact of NCs on patenting and Kang and Fleming (2017) on market structure. A related set of papers looks at the Inevitable Disclosure Doctrine (IDD), a judicial doctrine that restricts mobility for certain workers with access to trade secrets (Png and Samila 2013, Liu 2016, Qiu and Wang 2016). The contribution of this paper is the focus on the entrepreneurship-investment trade-off, and the use of LinkedIn data to provide detailed evidence on a much broader base of occupations and movement types than was previously possible.

Finally, this paper contributes to the discussion on labor mobility and business dynamism (Decker et al. 2014) by investigating a particular factor that impedes the reallocation of human resources in the economy. I show NC enforcement has a large impact on firm entry, but also present a potential drawback of limiting NC agreements. Quantifying this trade-off is particularly important in light of recent proposals to limit

\footnotetext{
${ }^{4}$ This is not necessarily contradictory with the result from Garmaise (2011), since I look at investment-tocapital, while Garmaise (2011) looks at investment-to-labor. In my setting I do not find a result statistically different from zero when I look at the investment-to-labor ratio.

${ }^{5}$ Babina (2015), Matray (2014) and Samila and Sorenson (2011) also reference NCs, but as a moderating factor on their main mechanisms.
} 
the use of NCs at both the state and federal levels. While the intention is to spur dynamism, policy makers appear to ignore the potential impact on existing firms (White House Report 2016). In my setting, mobility restrictions generate substantially higher capital investment at existing knowledge-intensive firms. Because NCs are a form of private ordering, government intervention into this arrangement needs to justify reallocating resources from one set of agents (e.g., existing firms) to another set of agents (e.g., entrepreneurs). Plausible justifications could include frictions such as asymmetric information between the agents, or inefficient externalities generated by the arrangement - e.g., if there are externalities to new firm entry. While this is beyond the scope of this paper, the aim of the analysis is to provide a stepping stone to answer these questions.

The remainder of the paper is structured as follows. Section 2 explains the NC policy setting, and Section 3 describes the data. Section 4 outlines the hypotheses and empirical approach. Section 5 presents the results, and Section 6 concludes.

\section{Empirical Setting: Non-Compete Agreements $(\mathrm{NCs})$}

\subsection{Prevalence of NCs}

In a survey of about 11,000 U.S. labor force participants, Starr et al. (2018) find that $38 \%$ of workers have at some time signed a NC, and that $18 \%$ are subject to one at the time of the survey. NCs are more common for more knowledge-intensive positions: Starr et al. (2018) estimate that $39 \%$ of college-educated workers and those earning more than $\$ 100 \mathrm{k}$ have NCs, and 35\% of those in architecture, engineering or computer and mathematical occupations are subject to a NC. Senior employees and in particular 
executives are also more likely to have NCs: Garmaise (2011) finds evidence of NCs for top executives in $70 \%$ of the public companies he examines. Nonetheless, NCs are prevalent across occupations: About one in 10 employees without a Bachelor's degree and earning less than $\$ 40 \mathrm{k}$ annually is subject to a NC (Starr et al. 2018). Figure A.4 contains the full information from Starr et al. (2018) on NC incidence by occupation. Anecdotally, news organizations from the Wall Street Journal to the Washington Post and the Atlantic have reported on the increased prevalence of NCs over the past 15 years, including in relatively unskilled positions 6

\subsection{NC Enforceability}

NCs are governed at the state level, and there is wide variation across states in the type of NCs that are permitted and how they are enforced. At one extreme, California bans the use of NCs. At the other extreme, several states allow enforcement of NCs even for employees who are laid off. Bishara (2011) identifies six broad dimensions of enforcement: 1) whether a state statute exists, 2) the employer's protectable interests, 3) the plaintiff's burden of proof, 4) whether NCs can apply to terminated employees, 5) consideration, and 6) modification. Consideration refers to the requirement in contractual law that both parties must receive something in order for a contract to be valid. In the case of NCs, many states consider continued employment in and of itself to be sufficient consideration; others require any new $\mathrm{NC}$ or $\mathrm{NC}$ amendment to be paired with a material benefit to the employee, e.g., a promotion (Starr 2018).

Modification, also called reformation or blue/red pencil doctrine, refers to the way in which courts deal with overly broad restrictions. To illustrate this, Kenneth J. Vanko,

\footnotetext{
${ }^{6}$ The Wall Street Journal, Feb. 2, 2016, "Noncompete Agreements Hobble Junior Employees"; The Washington Post, Feb. 21, 2015, "The Rise of the Non-compete Agreement, From Tech Workers to Sandwich Makers"; The Atlantic, Oct. 17, 2014, "How Companies Kill Their Employees' Job Searches."
} 
an Illinois attorney who maintains a blog on NC law, provides a useful example 7 Consider the following fictional NC:

"Employee agrees not to work in any sales capacity for any business competitive with the Employer for a period of six months in the following Illinois counties: Cook, DuPage and Kane."

Suppose the court considers this agreement overly broad because the employee only sold to customers in Cook County, and the agreement includes DuPage and Kane counties. If the state does not allow for any form of modification, that means the NC is simply unenforceable. The court cannot modify it to apply only to Cook County. If the state allows a "blue pencil" approach, the court may strike out portions of the agreement to make it enforceable, but they may not make any other changes. In this example, they can strike out DuPage and Kane counties to make the agreement enforceable, but they cannot modify the prohibited activity ("any sales capacity"). They would need a "red pencil," or reformation, to modify the language to another or more limited occupation. A consequence of the reformation approach is that employers have an incentive to draft NCs as broadly as possible, knowing that an overly broad contract will not disqualify their case but that it may dissuade employees from a broader range of activities (Thomas, Bishara and Martin 2014).

Building on these six dimensions identified by Bishara (2011), Starr (2018) constructs an index of NC enforceability for 1991 and 2009. In Table 2, I show that treated and control states were at similar levels of NC enforceability in 2009.

\footnotetext{
${ }^{7}$ The example and full discussion are available at http://www.non-competes.com/2009/01/quick-stateby-state-guide-on-blue.html
} 


\subsection{Changes in Enforceability}

NCs are governed by both statute and precedent, meaning that a case is determined by both the law that the state has in place, and case law established by previous rulings. Table A.1 outlines the NC enforcement changes that I use for my empirical setting: seven state Supreme Court rulings and one change from the state legislature.

I identify seven state supreme court rulings between 2009 and 2013 by combing through practitioner blogs, and verify all cases using Westlaw, a leading provider of data for legal professionals. I focus on rulings from states' highest courts because these represent the "final word" for state law and apply to the entire state. (Note that state high courts do not always have the name "supreme court," but in my sample the two are synonymous.) Finally, for each case I search for what local attorneys wrote about the expected impact of the decision, and verify that it is consistent with my interpretation 8 If the decision took place in the last three months of the calendar year, I assign the following year as the relevant first year of change. Court decisions are retroactive in the sense that they affect the enforceability of all NCs going forward, including NCs entered into before the decision was issued.

Two of the states merit further note. In Illinois, the state supreme court's decision to expand the scope of business interests in Reliable Fire Equipment v. Arredondo et al. was followed the next year by an appellate court decision (which the state supreme court declined to revisit) that decreased the enforceability of NCs. To reflect this, I code Illinois as an increase in 2012 but no longer an increase in 2013 9 In Montana, the

\footnotetext{
${ }^{8}$ For example, the law firm Jackson Lewis writes of the Colorado decision "The ruling will impact Colorado employers' decision about how and when to implement non-competition agreements." The law firm Beck Reed \& Riden writes of the Texas decision "Texas has just become much more favorable to employers than it has been in the last two decades." The law firm Seyfarth Shaw writes of the Virgina decision "There can be no doubt that the [Virginia] decision will invigorate employers to enforce noncompete agreements and make employers more reluctant to hire employees who are subject to noncompete provisions." I find similar statements for all rulings.

${ }^{9}$ For a discussion of this reversal, see The National Law Review, Oct. 22 2013, "Non-Compete Agreements:
} 
decision concerns the applicability of NCs to terminated employees and is therefore a more narrow change. I verify that my results are robust to excluding Montana.

During my sample period, in 2011, Georgia also passes a law allowing modification. With law changes, we may be more concerned about anticipation or lobbying than court decisions. In Georgia's case, there was in fact substantial uncertainty leading up to the change 10 The statute change is also not retroactive: employers must secure new NCs with their employees in order to benefit from modification. I include the Georgia change in my main specifications, but also verify that all of my results are robust to removing the state.

\subsection{State Supreme Court Composition and Political Con- text}

Table A.2 shows the composition of the state supreme courts for the seven states in which I observe the relevant rulings. On average, the courts are composed of seven justices serving terms of 10 years. Of these, only the Montana, Texas, and Wisconsin justices face contested re-election. Judges on these courts were on average six years from re-election at the time of their decisions, suggesting their rulings were unlikely to be affected by immediate re-election concerns. In Colorado and Illinois, justices face uncontested retention re-elections, and in South Carolina and Virginia, justices are re-appointed by the state's general assembly. In these four states, justices were on average seven years from re-appointment at the time of their decisions.

The "treated" states constitute a geographically and economically diverse group of states. Figure A.1 shows the geographic location of these states. In Section 4 , I show

Lessons from Illinois Courts." Results are robust to handling this change in different ways.

${ }^{10}$ For a discussion of this, see "What Georgia's Restrictive Covenant Act Means - and Doesn't Mean - for Employers," available at https://www.tradesecretslaw.com/2011/05/articles/noncompeteenforceability/what-georgias-restrictive-covenant-act-means-and-doesnt-mean-for-employers/ 
these states are similar to the control states in terms of ex-ante political and economic characteristics. In particular, Figure 2 shows that GDP per capita follows very similar trends in treated and control states. This suggests the changes in enforceability are not simply a response to a relatively better or worse environment in the treated states.

\subsection{Non-compete Enforcement and Mobility}

The main mechanism through which NC enforcement restricts labor mobility is deterrence. To be specific, there are several (complementary) ways increased enforceability may deter employees from leaving. First, higher enforceability can mean that there are more cases brought to court, and more cases where an employee is found to be at fault, which can discourage employees uncertain about leaving. Figure A.2 shows that since 2008, courts have decided about 900-1,000 NC cases every year. This number does not include cases that were settled, not to mention disputes that did not reach courts. Second, employees who seek legal advice about a potential move will be counseled differently following a change in enforceability. For example, following Texas' decision in Marsh v. Cook (2011), attorneys may counsel employees that the risk of litigation for a $\mathrm{NC}$ breach has increased 11 Third, employers can and do remind workers of their obligations ${ }^{12}$ Fourth, prospective employers refrain from hiring workers who are likely subject to NCs 13 Fifth, in the case of modification, employers have incentives to draft broader NCs going forward (Thomas et al. 2014). Finally, there

\footnotetext{
${ }^{11}$ E.g., "Texas covenant not to compete law dramatically changed in June 2011. ... Legal advice you previously received concerning your non compete's enforceability no longer may be current." As of February 2018, a search for non-compete enforceability in Texas could land you on the non-competes home page of Hersh law firm (a Dallas non-compete law firm), with exactly that text. https://www.hersh-law.com/noncompetes.html

${ }^{12}$ See Kenneth Vanko's blog, www.non-competes.com, Dec. 31 2010. "It is fairly standard now for any departing employee to receive a not-so-friendly reminder from an ex-employer about the terms of a noncompete agreement."

${ }^{13}$ For an example, see The Wall Street Journal, Feb. 2, 2016, "Noncompete Agreements Hobble Junior Employees."
} 
could also be a peer effect: As fewer colleagues move to or establish a new firm, this could reduce the motivation for an employee to follow that path.

For prosecution of NCs, the relevant jurisdiction is typically the place of performance of the economic activity (Lester and Ryan 2010). I gather information on employee location from LinkedIn, and assign firms to the state in which they have the most employees (the "main state"). I show that the effect is stronger when I restrict the sample to more concentrated firms, e.g., where a minimum of $20 \%$ or $40 \%$ of employees are located in the main state. I discuss this further in Section 5 .

\section{Data}

\subsection{LinkedIn Data}

In 2015, LinkedIn selected a small number of researchers to be part of its Economic Graph Challenge. Awardees were granted access to detailed de-identified data from LinkedIn's platform. The data contain no name information and numerical member identifiers in the data were hashed.

LinkedIn is an online professional networking platform, which began in 2003 and has since grown to over 450 million users worldwide. For this paper, I use employment histories for active members in the U.S., i.e., employees who have been to the website at least once in the 60 days before the snapshot was created. About 52 million employment histories fall into this category during my sample period, or roughly one third of the US workforce.

Users' profiles are essentially online CVs, listing the history of where they have worked and in what capacity, as well as where they went to school and other interests. I use the start years and end years from this history, along with information on the 
employers, to create a panel of employee movements between firms. An individual does not have to be a LinkedIn member at the beginning of my sample period to be present at the beginning of my sample. For example, an individual could have become a LinkedIn member in 2015 but posted her employment history going back to 2005; that employment history would be in my sample starting in 2005.

LinkedIn standardizes employer information, including industry, year founded, size and employer type (e.g., private company, government entity). The platform also standardizes position-level information such as occupation and seniority level. This information allows me to properly aggregate all individuals working for the same firm, and to identify employees and departures of particular interest (e.g., employees in knowledge-intensive occupations, moving to a firm in the same industry or a position of relatively higher seniority).

I match firms in LinkedIn to publicly-held firms in the Compustat database in order to observe firm investment, and to link to observable characteristics such as size and NAICS industry. Figure A.3 shows the coverage of LinkedIn by sector for this matched sample. I calculate the ratio of active members employed in each sector in 2014 to the number of employees reported on Compustat for the same firms. The aggregate coverage rate is $30 \%$. The figure indicates that my sample over-represents knowledge-intensive sectors. Generally, this type of over-sampling of one group might represent a concern for external or internal validity. However, I argue this is not the case here. In terms of external validity, knowledge-intensive sectors are precisely the population of most interest in this paper. This is both because these sectors represent occupations that are most likely to be affected by NCs (see Figure A.4), and because these companies likely depend more on human capital for their production function. In terms of internal validity, I include industry-year and firm fixed effects throughout my empirical analysis to absorb any baseline differences that may exist 
across industries. The estimates represent within-firm, within-industry-year relative differences in outcome variables. Section 4.2 discusses this in detail.

We may be concerned that individuals lie about their past employment history. However, unlike lying on a resume that only a prospective employer will see and cannot easily verify, lying on a LinkedIn profile is publicly visible. That public accountability makes it more difficult for individuals to make false claims about their employment. Alternatively, we may be concerned about individuals who forget to update their profile. I address this issue in two ways: First, I restrict the data sample to active members, to avoid capturing "zombie" accounts. Second, I use data from a 2016 snapshot of employment histories. This leaves ample time for individuals to update their 20082014 employment histories. Combined with the requirement that they be active on the site in 2016, this should minimize the number of individuals with incorrect information about their employment before 2014 .

An individual counts as employed at company $\mathrm{A}$ in year $\mathrm{t}$ if she lists a job at company A at any time during year t. She is considered as a departure in year $t$ if she is no longer employed at company $\mathrm{A}$ in year $\mathrm{t}+1$. The departure rate of a firm is its number of departures scaled by the number of employees as measured on LinkedIn. I use the total number of employees throughout to make sure results are driven by the numerator, and not by a changing denominator, and also to make the interpretation of triple differences estimations more straightforward. In untabulated results I also verify that the results are robust to using the Compustat number of employees in the denominator instead.

Table 1 Panel A contains summary statistics for departure rates. All variables are scaled by the total number of employees, so the total departure rate is mechanically higher than all other departure rates. The total average departure rate is $9.27 \%$ (median $8.00 \%$ ), and the average knowledge worker departure rate is $4.71 \%$ (median 
$3.45 \%$ ). In other words, knowledge workers represent roughly half of all departures. The former number is relevant in interpreting results from the generalized difference-indifferences specification, while the latter is useful for the triple differences specification. Panel A also shows the average departure rate to newly founded firms, and to newly founded firms with a "founder" title.

I also use LinkedIn company pages to measure the entry of new firms. Using year founded, location, and industry, I create an industry-state panel of new firms entering the economy. I restrict the data to private companies to avoid capturing spin-offs and mergers, and exclude financial firms. Since these are private firms, I use the industry classification provided within LinkedIn, which contains roughly 130 unique industries. To make numbers comparable across states, I scale the number of newly founded firms by population. In Table 1 Panel C, I show summary statistics for both scaled and unscaled observations, for easier interpretation. The unit of observation is state-yearindustry. The average number of firms entering per year per industry per state is 2.53 , while the median is 1 .

These data are the best way to capture new firm entry for my setting (relative to other available data) for several reasons. First, new firms on LinkedIn are more likely to capture the kind of growth entrepreneurship that matters for this particular question of trade-offs with investment, relative to Census-derived numbers of new firm starts which are designed to capture new firm starts indiscriminately (e.g., place equal weight on flower shops and tech start-ups). Moreover, the Bureau of Business Dynamics (BDS) statistics available by state and year are aggregated in very broad sectors, with nothing that would map to a technology sector. Finally, BDS counts the number of opening establishments from new firms. This creates a potential problem both for new firms that open multiple establishments in a year, and for new firms that do not open establishments, such as new ventures operating out of homes or co-working spaces. 


\subsection{Investment Data}

I use Compustat data to measure the investment response of firms. To avoid bias from mergers or acquisitions, I exclude firm-year observations with more than $100 \%$ growth in sales or assets. I also remove financial and regulated industries, and exclude observations with missing stock market data.

I define net investment as capital expenditures less the sale of property (Compustat capxv - sppe), and scale by one year-lagged net capital (Compustat ppent) to obtain the investment rate, $I / K$. I winsorize the top and bottom $1 \%$ and exclude observations with less than 0.5 million in net capital. These steps are to ensure that my sample is focused on the most relevant observations and that my estimates are not driven by outliers, but my results are robust to less stringent cleaning as well. I choose to scale investment by net capital because the firm's investment decision occurs each period, and so is conditional on the depreciated stock of capital in that period. However, results are qualitatively similar when I scale by gross capital or assets instead.

Table1 Panel B presents summary statistics for this sample. The average net capital investment rate is 0.30 , and the median 0.22. Knowledge firms - firms employing a higher than median fraction of knowledge workers - have slightly higher but similar investment rates, and tend to be slightly smaller.

\section{Hypotheses and Empirical Approach}

\subsection{Hypothesis Development}

\section{A) Non-competes and Labor Mobility}

NCs are contracts designed to prevent employees from leaving to competing occupations - and anecdotally, sometimes designed to prevent employees from leaving 
full stop 14 Existing literature has documented that $\mathrm{NC}$ enforceability is related to decreased mobility for specific occupations (inventors (Marx et al. 2009), executives (Garmaise 2011), physicians (Lavetti et al. 2014)). As a result, the baseline hypothesis of the paper is that an increase in $\mathrm{NC}$ enforceability should negatively impact departure rates.

Because of the granularity of the data, I am able to examine more specific hypotheses. In particular, NCs target moves to competing occupations, so one hypothesis is that departures to positions in the same industry should be particularly impacted. Similarly, NCs especially target moves that build on experience, so departures to relatively more senior positions should be especially impacted. Departures to less senior positions, to the extent they contain some involuntary departures, should be less impacted.

Finally, while NCs affect a large number of workers, knowledge-intensive occupations have a higher incidence of NCs (Starr et al. 2018). As a result, the impact of NCs should be especially driven by workers in these occupations.

\section{B) Non-competes and Entrepreneurship}

Just as NCs preclude individuals from moving to a competitor, they preclude individuals from establishing a competitor. Thus in a very direct sense, an increase in the enforceability of NCs should preclude some individuals from leaving to join or start a new firm. However, the impact on overall firm entry is less direct. For example, it could be the case that investment opportunities no longer pursued by employees subject to NCs will be seized by individuals not limited by these agreements (e.g., graduating students, other types of workers). In that case there would be no overall impact on the creation of new firms. At the same time, most entrepreneurship emanates from ideas encountered in previous employment (Bhide 1994), and experienced entrepreneurs tend

\footnotetext{
${ }^{14}$ The Atlantic, Oct. 17, 2014, "How Companies Kill Their Employees' Job Searches."
} 
to be more successful (Franco and Mitchell 2008). As a result, I hypothesize that new firm entry will also decline in response to stronger enforceability of NCs, in particular in knowledge-intensive sectors, as a result of these types of workers no longer being able to leave to join or start new firms.

C) Non-competes and Firm Investment

Consider a typical firm with two inputs to production: physical capital and human capital. Here, human capital combines both the number and quality of the workers - the same way that physical capital captures not the number of machines but their value, we can think of human capital as capturing the knowledge and skills embodied in the firm's workforce. I assume that workers become more valuable to the firm as they gain more tenure, either because they learn firm-specific expertise on the job, or because they gain general skills and search frictions make replacement difficult, or both. This is especially true in more knowledge-intensive occupations, where there are more opportunities to gain expertise, and human capital is not easy to automate and thus replace.

In the same way that we typically have a depreciation rate for physical capital, we can thus think of a depreciation rate for human capital, which would capture deterioration from increased turnover (decreased average tenure). Intuitively, high turnover in the workforce is costly for firms because it prevents knowledge - human capital from accumulating. There is also a potential effect of uncertainty: since it can be hard to properly gauge the quality of prospective hires, high turnover can also increase uncertainty about the quality of human capital tomorrow. In this setting, making it easier for workers to leave (e.g., by decreasing NC enforceability) is akin to increasing the average and volatility of the depreciation rate of human capital. Conversely, increasing NC enforceability, which increases workforce tenure, represents a decrease in the average and volatility of the human capital depreciation rate. 
The impact on the firm's investment into physical capital then depends on whether the two inputs are complements or substitutes. If physical and human capital are complementary - say, because equipment requires skilled labor to operate - then physical capital investment will increase when turnover decreases and human capital accumulates more rapidly. If they are substitutes - say because the tasks performed by human capital can be automated - then physical capital investment will decrease with labor mobility. For knowledge-intensive occupations, detailed in Section 4.2, I expect the relationship to be complementary, as these occupations are harder to automate (Autor and Dorn 2013).

I therefore expect knowledge-intensive firms to increase capital investment in response to stronger restrictions on labor mobility. This intuition is consistent with Bolton, Wang and Yang (2018), who argue that inalienable human capital can lead to under-investment (in physical capital) when the employee's outside option is high. Not coincidentally, NCs are more common in occupations that are knowledge-intensive, since their goal is to preserve valuable human capital. This reinforces the hypothesis that an increase in the enforceability of NCs will translate to more investment in knowledge-intensive firms.

\subsection{Methodology}

I use a generalized difference-in-differences approach with NC enforcement changes as my treatment of interest. The specification is as follows, for company $i$ in industry $j$, state $s$ and year $t$ :

$$
y_{i j s t}=\alpha+\beta\left(\text { treated }_{s} * \text { post }_{t}\right)+\gamma_{i}+\theta_{j t}+\epsilon_{i j s t}
$$


where treated $*$ post is 1 for an increase in enforceability relative to 2008,0 for no change, and -1 for a decrease in enforceability. I make this symmetric assumption for convenience. Most of the changes that I use have a similar magnitude in the framework of the enforceability indexes constructed by Starr (2018) and Bishara (2011). However, if I decompose treated $*$ post into increased $*$ post and decreased $*$ post - a separate indicator for states where enforcement increases and where it decreases - I obtain very similar estimates for increased $*$ post as for treated $*$ post, and for decreased $*$ post, the estimate is of similar magnitude but with the sign flipped and not statistically significant. The lack of statistical significance is not surprising given the much fewer observations in this group.

I include company fixed effects $\gamma_{i t}$ and industry-year fixed effects $\theta_{j t}$ in all regressions, with industry defined as four-digit NAICS code. I cluster all errors at the state level, because that is the level of treatment. All 50 states enter the regressions - the untreated states enter as controls - so there is a sufficient number of clusters. I do not include time-varying firm controls such as firm size, because such controls could be affected by the treatment, and cause inconsistent estimates of the treatment effect. However, I find similar results when I include log market capitalization, assets, and employee size. Note that firm fixed effects absorb any time-invariant differences across firms, and industry-year fixed effects absorb any time-varying differences across firms at the four-digit NAICS level.

The main assumption underlying this approach is that absent the NC enforcement changes, the average change in the treated and control groups would have been the same - the two groups would have continued to experience parallel trends. The coefficient estimate on treated $*$ post captures the additional change in treated states, relative to untreated states, following a change in $\mathrm{NC}$ enforcement.

In Figures 1, A.5, and A.6, I show that there was no anticipation or differential 
trend between both groups prior to the treatment, in terms of each of the main outcome variables. For example, for Figure 1 I estimate the following equation:

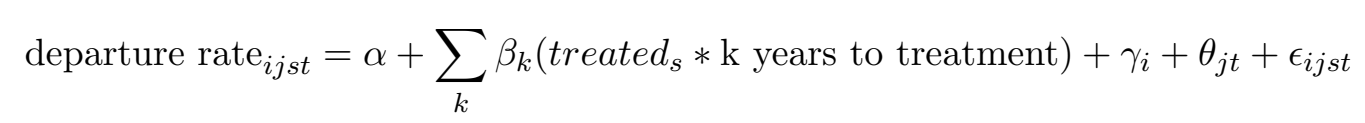

Figure 1 plots the estimates of the event study: The coefficient estimate on treated $*$ $k$ years to treatment against $k$ years to treatment. Prior to the enforcement change, the estimated difference between the treatment and control groups is virtually zero. However, following the change in enforcement, the departure rate in the treatment group drops significantly relative to the departure rate in the control group. The omitted variable is the difference three or more years prior to treatment 15

In Table 2, I report political and economic characteristics for eventually treated and control states, prior to the start of my sample. Having the same ex-ante levels of observables is not a necessary condition for the identifying assumption - trends can be at different levels as long as they are parallel - but similar ex-ante characteristics reinforce the assumption that the average change in both groups would have been the same absent treatment. There are four columns of statistics in Table 2 , The first shows the ex-ante mean for states in which NC enforcement does not change in my sample period (Never Treated). The second shows the ex-ante mean for all states in which NC enforcement changes during the sample period (Eventually Treated). I then break this group into two groups, based on whether NC enforcement increases or decreases. The last group contains only Montana and South Carolina, which are the two states that experience a decrease in the enforceability of NCs. Note that while I include pvalues for the t-test of differences in Table 2 for completeness, these are only marginally

\footnotetext{
${ }^{15}$ Only Illinois and Virginia have information four or more years prior to treatment, as the changes there occur in 2012 and 2013. Similarly, only Wisconsin has information four and five years after treatment (the change there occurs in 2009). As a result, I group these years with three years pre and post. Note that industry-year fixed effects still separately absorb the time trends for each calendar year.
} 
informative given the small size of the sample involved.

Looking at these political and economic characteristics, treated and control states seem overall similar. An exception is that Montana and South Carolina have lower average GDP per capita and are more conservative than the rest. Regression results are robust to excluding these two states. Figure 2 shows the trend in GDP per capita for the different groups, taking a population-weighted average across states (the figure looks very similar if the average is instead equal-weighted). This shows the level difference between states where enforcement decreases, relative to both control states and states where enforcement increases. It also shows that trends track very closely across the three groups. If anything, there is a slight separation of trends after 2011, but from 2008 to 2011 (the main pre-period) the trends track in lock-step, giving further confidence that the parallel trends assumption is satisfied.

In order to further focus on the most relevant workers and firms, I separate out occupations most likely to be affected. To do this, I rely both on survey data from Starr et al. (2018) on NC incidence by occupation, and on educational attainment statistics from the Bureau of Labor Statistics (BLS). Figure A.4 reproduces the incidence of NCs by occupation found in Starr et al. (2018). Looking at both the multiple imputation incidence estimate and the within-occupation projection, I consider occupations starting from "Life, Physical, Social Sciences" and up through "Architecture, Engineering" to be high-NC occupations. LinkedIn's classification scheme provides one category for healthcare services, so combining "Physician, Technical" and "Healthcare Support" estimates, I also consider healthcare services to be high-NC occupations.

I then turn to educational attainment in each occupational category. I use statistics from the BLS to approximate the percentage of workers in each occupation holding a bachelor's degree or higher, and the average years of education (high school and above). Table A.3 reports these figures. A rank ordering by either educational measure yields 
almost the same list as the high-NC occupation list (again, combining healthcare occupations), with two exceptions: legal occupations, and community service occupations. Indeed, the American Bar Association holds that NCs applied to lawyers are unethical, and its Rule of Professional Conduct prohibits lawyers from creating an agreement that "restricts the right of a lawyer to practice after termination of the relationship" (Horvitz 2016). Even without legal and community service occupations, $60 \%$ of employees in high-NC occupations have a bachelor's or higher, compared to $19 \%$ in other occupations.

As a result, I define the following LinkedIn occupation categories as my main occupations of interest, and label them "knowledge workers": arts \& design, business development, consulting, education, engineering, entrepreneurship, finance, healthcare services, information technology, media \& communication, product management, program \& project management, and research. Results are robust to including legal and community service occupations into this definition. Knowledge workers represent close to half $(44 \%)$ of the workers for the average firm in my sample. Knowledge firms are firms which employ a greater than median fraction of knowledge workers. I use this classification and high R\&D intensity as ways to proxy for firms that are more dependent on human capital 16

To compare the impact of higher NC enforceability on knowledge workers with the impact on all workers, I estimate a difference-in-difference-in-differences (or "triple differences") specification. This specification starts from the benchmark of equation 1 . then interacts all terms with an indicator for knowledge workers (or knowledge firms or knowledge sectors, as applicable: each table contains the appropriate specification). As an example, for departure results, the unit of observation is at the firm-year-occupation

\footnotetext{
${ }^{16}$ More than $50 \%$ of R\&D is wages paid to research activities (Hall and Lerner 2010), suggesting R\&D intensity is a reasonable proxy for a firm's dependence on skilled human capital.
} 
type level. Thus for company $i$ in industry $j$, state $s$ and year $t$, the specification is:

$y_{i k s t}=\alpha+\beta_{1}\left\{\operatorname{treated}_{s} * \operatorname{post}_{t} * \mathrm{KW}_{k}\right\}+\beta_{2}\left\{\operatorname{treated}_{s} * \operatorname{post}_{t}\right\}+\gamma_{i}+\lambda_{k s}+\theta_{k t}+\epsilon_{i t}$

$K W$ is an indicator which takes the value of 1 if the occupation is knowledge-intensive, and 0 otherwise. The specification still includes company fixed effects $\gamma_{i t}$, as well as knowledge worker-year fixed effects $\theta_{k t}$ and knowledge worker-state fixed effects $\lambda_{k s}$. These interacted fixed effects absorb other terms that would normally appear in a triple difference, such as $K W^{*}$ post and $K W^{*}$ treated. I continue to cluster errors at the state level. The coefficient estimate on treated ${ }^{*}$ post $^{*} K W$ represents how much more knowledge-intensive occupations respond to the NC enforcement changes, relative to other occupations.

\section{Results}

\subsection{Employee Mobility}

To verify that $\mathrm{NC}$ enforcement impacts mobility, I first look at the impact of the changes in NC enforceability on departure rates overall. Table 3 Panel A shows results from a difference-in-differences regression of departure rate on an indicator for increased NC enforceability (equation 1). The sample universe is public companies matched between LinkedIn and Compustat. The unit of observation is firm-year. Following an increase in $\mathrm{NC}$ enforceability, the total departure rate drops by 0.73 percentage points, which represents $8 \%$ of a $9.3 \%$ average departure rate. In columns (2) and (3), I separate out departures to jobs in the same industry from departures to jobs in a different industry. The estimate for within-industry departures is statistically significant and represents a $12 \%$ drop relative to average. The estimate for out-of- 
industry departures is not statistically significant and represents a smaller economic magnitude as well, $5 \%$ relative to average. This is consistent with the fact that NCs particularly target moves to competing occupations.

Next, I separate out departures by the seniority level of the new position relative to the employee's old position. For example in column (4), the outcome reflects the subset of departures where the employee's new position is of higher seniority than the position that employee left. This is of particular interest because moves to a more senior position (or a position of equal seniority, as in column (5)) are more likely to capture voluntary departures than moves to less senior positions. Moreover, moves where seniority increases might capture situations where a new position builds on the employee's prior experience, to justify the higher seniority. Consistent with this, increased enforceability of NCs leads departures to more senior positions to decrease substantially, by 39 basis points or $15 \%$ relative to the average rate. Departures where employees stay at the same seniority level decrease 28 basis points, or $6 \%$ relative to average, while the estimate for departures to lower seniority is not statistically significant and represents just a $3 \%$ change relative to average.

In Table 3 Panel B, I show that these results are driven by workers in knowledgeintensive occupations by estimating difference-in-difference-in-differences (or "triple differences") regressions (equation 3). These regressions compare the impact of higher NC enforceability on the subsample of occupations that Starr et al. (2018) identify as more prone to NCs, to the impact on all occupations. The coefficient estimate on treated* post $^{*}$ knowledge worker represents how much more knowledge-intensive occupations respond to the $\mathrm{NC}$ enforcement changes. For all categories except departures where seniority decreases, this estimate is negative, showing decreased departure rates are driven by knowledge workers. The results show less statistical significance, but improve when the treatment assignment becomes cleaner in Table 4 , as described below. 
To assign firm location, I aggregate information on employee location from LinkedIn, and assign firms to the state in which they have the most employees (the "main state"). This is to reflect the fact that the relevant law for NCs is typically that of the employee's location (Lester and Ryan 2010). In baseline regressions, I include all firms, regardless of how concentrated their employee base is. However, if a firm's employee base is very dispersed, then the treatment assignment is noisy. In Table 4, I show what happens to the estimates from Table 3 if I restrict the sample to firms with more concentrated footprints.

The panels mirror those from Table 3 , but for brevity I report only the main coefficient of interest: in Panel A, the estimate on treated ${ }^{*}$ post, and in Panel B, the estimate on treated ${ }^{*}$ post*knowledge worker. The first row in each panel reproduces the estimates in the full sample. In the second row, the sample is limited to firms with at least $20 \%$ of their employees in their state of assignment, and in the third row, to firms with at least $40 \%$ of their employees in their state of assignment. This means that, as we move down the rows, the treatment assignment gets more precise. A little less than a quarter of firms drop out from the first to the third row.

The results show that as the treatment assignment becomes more precise, the results become more significant, both statistically and economically. Specifically, this is true for the outcomes where we would expect NCs to matter most: total departures, withinindustry departures, and departures to positions of equal or greater seniority. For the remainder of the analyses, I show results for both the baseline and the subset of companies with at least $40 \%$ of employees in the main state, and consistently find that results are not only robust but larger for the latter set of firms. 


\subsection{Entrepreneurship}

One of the main concerns about NCs - apparent in both academic and non-academic literature (Saxenian 1994, Gilson 1999, White House Report 2016) - is that fewer experienced employees leave to start new businesses. This is especially important if firms started by experienced, skilled employees tend to be more successful than other new firms (Franco and Mitchell 2008).

To understand this issue, I first look at whether the pipeline for new firms is affected by looking at departures to newly founded businesses. Specifically, a business is new if it is founded within a year in either direction of the employee's departure. I again separate out the effect on knowledge workers, as in the previous section and following the discussion in Section 4 .

Table 5 shows the results of this analysis. The specification is as in equation 3 . In columns (1) and (2), I first look at the departure rate to newly-founded companies, in any capacity. In Columns (3) and (4), I look specifically at individuals who move to new firms where they list themselves as founders of the new firms. I present results both for the full sample and for the subset of firms with at least $40 \%$ of employees in the state of assignment.

The results suggest that an increase in NC enforceability discourages knowledge workers from leaving to start or join new firms, although non-knowledge workers appear to replace them to some extent. In the full sample, the estimates indicate an 8 basis point increase in the non-knowledge worker departure rate to new firms. This increase almost disappears for knowledge workers, but not quite: the total effect for knowledge workers is still positive in the full sample. However, looking at less dispersed firms in column (2), where treatment is more precise, the total effect for knowledge workers becomes negative. Specifically, the estimates suggest knowledge worker departures to 
start-ups decline $6.0 \%$ relative to average.

Looking specifically at departures to found a new firm yields a similar pattern. In the full sample, results are not statistically different from zero. In the restricted sample, the decline is larger and (weakly) statistically significant, suggesting an $8.4 \%$ decline in knowledge workers founding new firms, relative to average. The results are not strong, but taken together with previous results, provide some additional evidence of the channel through which NCs end up affecting new firm entry.

In Table 6, I turn to the number of new businesses founded per industry-year. If other workers replace those affected by NCs, then new firm entry may not change. However, if that replacement is imperfect, it may result in fewer new firms entering the economy. I focus specifically on 'knowledge sectors' mapping to knowledge worker occupations: 1) technology, 2) professional, scientific \& technical services, and 3) education \& training.

Column (1) reports results from a triple difference specification with knowledge sectors grouped together. In relative terms, the estimates suggest that following higher NC enforceability, the knowledge sector experiences an $18 \%$ decrease in new firms. To better understand the economic interpretation of the results, I break out this effect by sector. New firm entry declines $8 \%$ in the technology sector, $13 \%$ in professional, scientific \& technical services, and $29 \%$ in education \& training. As shown in Table 1. the largest overall of these sectors is the technology sector, followed by professional, scientific \& technical services, with education \& training a relatively small sector for new firm growth. 


\subsection{Capital Investment}

If stronger NCs lead to a decline in new firm entry, do they lead to an increase in investment elsewhere? In Table 7, I show that tighter restrictions on labor mobility consistently lead to a higher investment rate. Following the discussion in Section 4.1 and the results in Section 5.1, I expect that the response will be more pronounced in firms that are more dependent on specialized human capital. To test this, I run two triple differences using different proxies for knowledge-intensive firms: firms with a higher than median fraction of knowledge workers (knowledge firms), and firms with a higher than median R\&D intensity.

The results show that $I / K$ increases substantially with $\mathrm{NC}$ enforceability, and that this is driven by firms that are more dependent on specialized human capital. Specifically, the results indicate that overall, firms increase investment by $\$ 6 \mathrm{k}$ for every $\$ 100 \mathrm{k}$ of net capital. For knowledge firms, the estimate is $\$ 10 \mathrm{k}$ for every $\$ 100 \mathrm{k}$ of net capital, and for firms with high R\&D intensity, \$8k. Results for knowledge firms are very similar when limiting to firms with a more concentrated employee base. At first, the effect appears surprisingly large: Comparing to the average investment rate, the coefficient estimates imply an increase of $21 \%$, and even more in knowledge and high R\&D firms. However, the estimates make more sense in an economic context. Multiplied by the average net capital stock, the estimates indicate a total $\$ 24$ million increase in investment in knowledge firms and a total $\$ 22$ million increase in high R\&D intensity firms. Put in a different way, the median knowledge firm increases investment by $\$ 3.2$ million, and the median R\&D intensive firm by $\$ 2.8$ million. 


\subsection{Trade-off}

Both results taken together point to a tension in the impact of labor mobility restrictions: on the one hand, stronger enforcement of NCs leads to a decline in new firm entry, but on the other hand it leads to an increase in capital investment, at least at publicly-held firms. While these are only partial outcomes, it seems nonetheless valuable to understand how at least these two effects trade off against each other.

I take advantage of the fact that I observe both responses within the same natural experiment setting to get an approximation of the trade-off in my sample. First, I do a back-of-the-envelope exercise to gauge the aggregate loss of knowledge-intensive entrants in my sample of treated states. In Table 6, the observations are number of new entrants scaled by state population, at an industry-state-year level. I adjust by number of industries (for each sector) and population to get an estimated loss over all treated states, across these knowledge-intensive sectors. I also have to account for the fact that my sample only captures private firms for which I observe year founded on LinkedIn. To get a better approximation of the aggregate loss of knowledge-intensive entrants, I infer the coverage rate of my sample from the BDS database of the Census (about 5\%) ${ }^{17}$ Overall, my estimates imply an aggregate loss of about 3,500 knowledgeintensive entrants across treated states.

Second, I repeat the back-of-the-envelope approach to gauge the aggregate increase in capital investment in treated states. In Table 7 column 3 , the estimated increase in investment rate for a treated high $R \& D$ firm is the sum of the two coefficients, i.e. 0.0786. This number represents a dollar increase in capital investment scaled by net capital, at a firm-year level. I adjust by average net capital for high R\&D firms, and

\footnotetext{
${ }^{17} \mathrm{I}$ do not use the BDS data directly for my regressions for several reasons that I discuss in the data section. However, for the purpose of the back-of-the-envelope aggregation exercise, the BDS data provide the best available comparison point of which I am aware.
} 
also aggregate over the number of high R\&D firms in the treated states. ${ }^{18}$ Overall, my estimates imply an increase of a little over $\$ 6$ billion in capital investment coming from publicly-held high R\&D firms across treated states. The resulting trade-off is approximately $\$ 1.8$ million of additional capital investment for every lost firm entry, in knowledge-intensive sectors. An important caveat is that this counts only investment from publicly-held firms. I do not attempt to generalize the result to privately-held firms because I have no point of information for the investment behavior of these firms, or the number and size of these firms in my treated states. However, if privately-held firms respond in a similar way to publicly-held firms, we can think of the trade-off number here as somewhat of a lower bound on the actual trade-off.

\section{Conclusion}

Recent research and policy proposals have renewed the debate over labor mobility restrictions. In particular, one issue that has received a lot of attention is the enforcement of non-compete agreements (NCs), mostly for its potentially negative effects on knowledge spillovers and entrepreneurship (Samila and Sorenson 2011, Matray 2014). However, NC enforcement may be an important tool for firms to safeguard capital investments. Establishing and quantifying this trade-off is especially important in light of recently proposed regulation (White House Report 2016) that appears to miss the latter effect.

In this paper, I consider the impact of NC enforceability on two outcomes: entrepreneurship and capital investment. To address concerns about unobservable dif-

\footnotetext{
${ }^{18}$ As with new firm entry, I have to adjust for the fact that my sample does not contain all publicly-held high R\&D firms. This is not because companies lack LinkedIn pages. Rather, it is because the matching between Compustat and LinkedIn companies is mainly based on names. I capture about $40 \%$ of publiclyheld, high-R\&D firms in my matched sample. Since the purpose here is to gauge the aggregate effect, I multiply by the total number publicly-held high $R \& D$ firms rather than the number in my sample.
} 
ferences biasing cross-sectional results, I identify a series of recent legal changes to the enforceability of NCs in various states. I combine these with detailed data on employee movements from LinkedIn's wide-reaching database of employment histories. This allows me to pinpoint workers in knowledge-intensive occupations, as well as departures to newly founded small businesses to capture entrepreneurship.

I find that changes in the enforceability of NCs lead to substantial effects on both entrepreneurship and investment. The effects are particularly pronounced in knowledgeintensive occupations, where the average departure rate drops by a quarter. The median knowledge-intensive firm increases its investment rate by an estimated $\$ 3$ million annually. At the same time, the rate of entry of new firms in knowledge sectors declines by $18 \%$ relative to average.

These results point to an important trade-off of labor mobility restrictions, between encouraging the entrance of new firms on the one hand and investment at existing firms on the other hand. While the magnitudes are difficult to quantify, my estimates place the trade-off among knowledge-intensive firms at around $\$ 1.8$ million in capital investment (just from publicly-held firms) for every foregone entrant. A limitation of this study is that I cannot quantify the value of the marginal new firms or of the marginal investment, and I cannot capture all welfare-relevant outcomes. Nonetheless, this paper contributes to the existing literature by painting a more complete picture of labor mobility and policies that regulate it, and opens the door for future inquiries to refine quantitative estimates of the trade-offs involved. 


\section{References}

Acemoglu, Daron and Robert Shimer, "Holdups and Efficiency With Search Frictions," International Economic Review, 1999, 40 (4), 827-849.

Autor, David H. and David Dorn, "The Growth of Low-Skill Service Jobs and the Polarization of the US Labor Market," American Economic Review, 2013, 103.

, William R. Kerr, and Adriana D. Kugler, "Does Employment Protection

Reduce Productivity? Evidence from US States," The Economic Journal, 2007, 117.

Babina, Tania, "Destructive Creation at Work: How Financial Distress Spurs Entrepreneurship," Working Paper, 2015.

Bhide, 1994, "How Entrepreneurs Craft Strategies That Work," Harvard Business Review, 1994.

Bishara, Norman D, "Fifty Ways to Leave Your Employer: Relative Enforcement of Covenants Not to Compete, Trends, and Implications for Employee Mobility Policy," University of Pennsylvania Journal of Business Law, 2011, 13 (3).

Bolton, P., N. Wang, and J. Yang, "Liquidity and Risk Management, Investment, and Compensation with Inalienable Human Capital: Optimal Contracting and Corporate Valuation," Journal of Finance, 2018, forthcoming.

Chen, J., M. Kacperczyk, and H. Ortiz-Molina, "Labor Unions, Operating Flexibility, and the Cost of Equity," Journal of Financial and Quantitative Analysis, 2011, (46), 25-58.

Coase, Ronald H, "The nature of the firm," Economica, 1937, 4 (16), 386-405.

Conti, Raffaele, "Do Non-Competition Agreements Lead Firms to Pursue Risky R\&D Projects?," Strategic Management Journal, 2014, 35, 1230-1248. 
Decker, Ryan, John Haltiwanger, Ron Jarmin, and Javier Miranda, "The Role of Entrepreneurship in US Job Creation and Economic Dynamism," Journal of Economic Perspectives, 2014, 28 (3), 3-24.

Donangelo, Andres, "Labor mobility: Implications for Asset Pricing," The Journal of Finance, 2014, 69 (3).

Eiling, Esther, "Industry-Specific Human Capital, Idiosyncratic Risk, and the CrossSection of Expected Stock Returns," The Journal of Finance, 2013, 68 (1).

Franco, April M. and Matthew F. Mitchell, "Covenants not to compete, labor mobility, and industry dynamics," Journal of Economics and Management Strategy, 2008, 17 (3), 581-606.

Furman, Jason, "Business Investment in the United States: Facts, Explanations, Puzzles, and Policies," in "Reviving Private Investment" Remarks at the Progressive Policy Institute Washington, D.C. 2015.

Garmaise, Mark J., "Ties that truly bind: Noncompetition agreements, executive compensation, and firm investment," Journal of Law, Economics, and Organization, 2011, $27(2), 376-425$.

Gilson, Ronald J, "The Legal Infrastructure of High Technology Industrial Districts: Silicon Valley, Route 138, and Covenants Not to Compete," New York University Law Review, 1999, 74 (3), 575-629.

Hall, Bronwyn H. and Josh Lerner, "The Financing of R\&D and Innovation," in "Handbook of the Economics of Innovation" 2010.

Horvitz, Kevin D, "An unreasonable ban on reasonable competition: the legal profession's protectionist stance against noncompete agreements binding in-house counsel," Duke Law Journal, 2016, 65, 1007. 
Kang, Hyo and Lee Fleming, "Large Firm Advantage and Entrepreneurial Disadvantage: Non-competes and Market Concentration," Working Paper, 2017.

Lavetti, Kurt, Carol Simon, and William White, "Buying Loyalty: Theory and Evidence from Physicians," Working Paper, 2014.

Lester, Gillian and Elizabeth Ryan, "Choice of Law and Employee Restrictive Covenants: An American Perspective," Comparative Labor Law 8 Policy Journal, 2010.

Liu, Zack, "Intellectual Property Allocation and Firm Investments in Innovation," Working Paper, 2016.

Marx, Matt, Deborah Strumsky, and Lee Fleming, "Mobility, Skills, and the Michigan Non-Compete Experiment," Management Science, 2009, 55 (6), 875889.

Matray, Adrien, "The Local Innovation Spillovers of Listed Firms," Working Paper, 2014, pp. 1-61.

Png, I.P.L. and Sampsa Samila, "Trade Secrets Law and Engineer/Scientist Mobility: Evidence from "Inevitable Disclosure"," Working Paper, 2013.

Qiu, Buhui and Teng Wang, "Does Knowledge Protection Benefit Shareholders? Evidence from Stock Market Reaction and Firm Investment in Knowledge Assets," Working Paper, 2016.

Samila, Sampsa and Olav Sorenson, "Noncompete Covenants: Incentives to Innovate or Impediments to Growth," Management Science, 2011, 57 (3), 425-438.

Saxenian, AnnaLee, "Regional Advantage: Culture and Competition in Silicon Valley and Route 128," Cambridge, Mass.: Harvard University Press, 1994.

Schumpeter, Joseph A., "Capitalism, Socialism and Democracy," 1942. 
Starr, Evan, "Consider This: Training, Wages and the Enforceability of Covenants Not to Compete," Working Paper, 2018.

, J.J. Prescott, and Norman Bishara, "Noncompetes in the U.S. Labor Force," Working Paper, 2018.

Thomas, Randall S., Norman Bishara, and Kenneth J. Martin, "An Empirical Analysis of Non-Competition Clauses and Other Restrictive Post-Employment Covenants," SSRN Electronic Journal, 2014.

White House Report, "Non-Compete Agreements: Analysis of the Usage, Potential Issues, and State Responses," Technical Report, The White House 2016.

Zingales, Luigi, "In Search of New Foundations," The Journal of Finance, 2000, 55 (4). 


\section{Tables}




\section{Table 1: Summary Statistics}

This table reports summary statistics for key variables. Panels A and B contain information for publicly-held firms matched between LinkedIn and Compustat. Panel C contains information at the industry-state level for new firm entry, as measured by looking at privately-held firms with a LinkedIn page founded during the sample period 2008-2014.

\begin{tabular}{|c|c|c|c|c|c|c|}
\hline Variable & Obs & Mean & SD & $25 \%$ & $50 \%$ & $75 \%$ \\
\hline \multicolumn{7}{|l|}{ Panel A: Departure Rates } \\
\hline \multicolumn{7}{|l|}{ All workers together } \\
\hline Total departures & 11,524 & 9.27 & 8.37 & 4.55 & 8.00 & 12.11 \\
\hline Same industry & 11,524 & 3.34 & 4.94 & 0.74 & 2.27 & 4.35 \\
\hline Different industry & 11,524 & 5.92 & 6.25 & 2.38 & 4.83 & 7.87 \\
\hline Increase seniority & 11,524 & 2.56 & 3.60 & 0.61 & 2.00 & 3.45 \\
\hline Stay in seniority & 11,524 & 4.95 & 5.39 & 2.10 & 4.13 & 6.54 \\
\hline Decrease seniority & 11,524 & 1.77 & 3.53 & 0.00 & 1.11 & 2.20 \\
\hline To new firm & 11,524 & 0.32 & 1.24 & 0.00 & 0.00 & 0.26 \\
\hline To founder title & 11,524 & 0.04 & 0.23 & 0.00 & 0.00 & 0.00 \\
\hline \multicolumn{7}{|c|}{ Knowledge workers (scaled by total size) } \\
\hline Total departures & 11,376 & 4.71 & 6.04 & 1.42 & 3.45 & 6.15 \\
\hline Same industry & 11,376 & 1.69 & 3.51 & 0.00 & 0.85 & 2.06 \\
\hline Different industry & 11,376 & 3.02 & 4.54 & 0.34 & 2.07 & 3.91 \\
\hline Increase seniority & 11,376 & 1.30 & 2.47 & 0.00 & 0.77 & 1.67 \\
\hline Stay in seniority & 11,376 & 2.61 & 4.20 & 0.00 & 1.77 & 3.39 \\
\hline Decrease seniority & 11,376 & 0.81 & 2.53 & 0.00 & 0.29 & 0.88 \\
\hline To new firm & 11,376 & 0.18 & 0.92 & 0.00 & 0.00 & 0.08 \\
\hline To founder title & 11,376 & 0.02 & 0.20 & 0.00 & 0.00 & 0.00 \\
\hline \multicolumn{7}{|c|}{ Panel B: Investment \& Firm Characteristics } \\
\hline \multicolumn{7}{|l|}{ All firms } \\
\hline $\mathrm{I} / \mathrm{K}$ & 5,030 & 0.30 & 0.29 & 0.12 & 0.22 & 0.39 \\
\hline Investment & 6,048 & 56.68 & 177.82 & 0.56 & 5.56 & 30.23 \\
\hline Net Capital & 6,597 & 475.98 & $1,383.09$ & 8.68 & 49.81 & 263.25 \\
\hline Assets & 7,308 & $1,651.47$ & $4,169.39$ & 49.54 & 280.06 & $1,294.38$ \\
\hline Market Cap & 7,308 & $2,163.04$ & $7,504.00$ & 54.33 & 319.28 & $1,329.30$ \\
\hline \multicolumn{7}{|l|}{ Knowledge firms } \\
\hline$\overline{\mathrm{I} / \mathrm{K}}$ & 2,361 & 0.35 & 0.30 & 0.14 & 0.27 & 0.48 \\
\hline Investment & 2,998 & 36.80 & 113.70 & 0.37 & 4.03 & 21.29 \\
\hline Net Capital & 2,997 & 229.04 & 737.49 & 6.17 & 30.57 & 143.47 \\
\hline Assets & 3,464 & $1,352.77$ & $3,701.82$ & 38.02 & 211.24 & 934.03 \\
\hline Market Cap & 3,464 & $2,167.25$ & $7,181.87$ & 48.41 & 270.92 & $1,356.11$ \\
\hline \multicolumn{7}{|l|}{ Panel C: New Firm Entry } \\
\hline New firms & 31,850 & 2.53 & 8.95 & 0.00 & 1.00 & 2.00 \\
\hline New firms all sizes, p. million & 31,850 & 0.37 & 0.88 & 0.00 & 0.10 & 0.37 \\
\hline New firms - Education \& training & 1,001 & 1.77 & 3.46 & 0.00 & 1.00 & 2.00 \\
\hline New firms - Professional services & 6,447 & 3.98 & 12.51 & 0.00 & 1.00 & 3.00 \\
\hline New firms - Technology & 5,005 & 4.49 & 16.77 & 0.00 & 1.00 & 3.00 \\
\hline
\end{tabular}


Table 2: Ex Ante Political \& Economic Characteristics

This table reports ex-ante (2006-2007) means of political and economic characteristics for states where NC enforcement does not change, and for states where $\mathrm{NC}$ enforcement changes during the sample period. Below the means are p-values from a t-test of differences relative to the "never treated" observations, although given the small sample size p-values are only marginally informative. I further break out the treated states into states for which NC enforcement eventually increases (Colorado, Georgia, Illinois, Texas, Virginia, Wisconsin) and those for which it eventually decreases (Montana, South Carolina). The Partisan Voting Index comes from the 2010 Cook Political Report, and the NC enforceability score from the 2009 index constructed in (Starr 2018).

\begin{tabular}{|c|c|c|c|c|}
\hline & \multirow[b]{2}{*}{ Never Treated } & \multicolumn{3}{|c|}{ Eventually Treated } \\
\hline & & All & Increase & Decrease \\
\hline \multicolumn{5}{|c|}{ Political \& Economic Measures } \\
\hline \multirow[t]{2}{*}{ GDP growth, in pct } & 5.35 & 5.64 & 5.24 & 6.87 \\
\hline & $p=$ & 0.698 & 0.893 & 0.302 \\
\hline \multirow[t]{2}{*}{ GDP per capita, in thsds USD } & 48.24 & 44.53 & 47.50 & 35.63 \\
\hline & $p=$ & 0.453 & 0.896 & 0.201 \\
\hline \multirow[t]{2}{*}{ Unemployment rate, in pct } & 4.44 & 4.45 & 4.33 & 4.80 \\
\hline & $p=$ & 0.969 & 0.724 & 0.495 \\
\hline \multirow{2}{*}{ Partisan Voter Index } & $\mathrm{R}+2.4$ & $\mathrm{R}+3$ & $\mathrm{R}+1.5$ & $\mathrm{R}+7.5$ \\
\hline & $p=$ & 0.864 & 0.821 & 0.451 \\
\hline \multirow[t]{2}{*}{ CNC enforceability score } & 0.12 & -0.03 & 0.12 & -0.46 \\
\hline & $p=$ & 0.717 & 0.995 & 0.480 \\
\hline
\end{tabular}




\section{Table 3: NC Effect on Employee Departure Rates}

Panel A presents the results of difference-in-differences estimations with different departure rates as the dependent variables.

$$
100 * \frac{\# \text { departures }}{\# \text { employees }}_{i t}=\alpha+\beta\left\{\text { treated }_{i} * \text { post }_{t}\right\}+\gamma_{i}+\theta_{j t}+\epsilon_{i t}
$$

Panel B presents the results for corresponding difference-in-difference-in-differences estimations, where each firm is split into "knowledge workers" and other workers, and the treated*post term is interacted with an indicator for the knowledge worker sample.

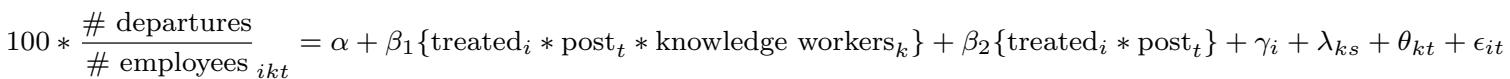

The dependent variable is a firm's departure rate in year $t$ in percentage points (1 to 100). In Column (1), the numerator is all departures. In Column (2), the numerator includes only departures where the origin and destination industries are the same. Column (3) is the complement, and includes only departures where the origin and destination industries are different. In Column (4), the numerator includes only departures to a more senior position than the employee was previously in. In Column (5), it includes only departures to a position of equal seniority, and in Column (6) of lesser seniority. The denominator is the same throughout, so Columns (2)-(6) are subsets of Column (1) - mechanically, the number is highest in Column (1). Standard

\begin{tabular}{|c|c|c|c|c|c|c|}
\hline & $\begin{array}{c}(1) \\
\text { Total } \\
\text { departures }\end{array}$ & $\begin{array}{c}(2) \\
\text { Same } \\
\text { industry }\end{array}$ & $\begin{array}{c}(3) \\
\text { Different } \\
\text { industry }\end{array}$ & $\begin{array}{c}(4) \\
\text { Increase } \\
\text { seniority }\end{array}$ & $\begin{array}{c}(5) \\
\text { Stay in } \\
\text { seniority }\end{array}$ & $\begin{array}{c}(6) \\
\text { Decrease } \\
\text { seniority }\end{array}$ \\
\hline Treated*Post & $\begin{array}{c}-0.731^{* * *} \\
(0.248)\end{array}$ & $\begin{array}{c}-0.406^{* * *} \\
(0.143)\end{array}$ & $\begin{array}{l}-0.317 \\
(0.196)\end{array}$ & $\begin{array}{c}-0.392^{* * *} \\
(0.129)\end{array}$ & $\begin{array}{c}-0.277^{* *} \\
(0.128)\end{array}$ & $\begin{array}{c}-0.0612 \\
(0.128)\end{array}$ \\
\hline $\begin{array}{l}\text { Observations } \\
\text { R-squared } \\
\text { Industry-Year FE } \\
\text { Company FE }\end{array}$ & $\begin{array}{c}7,063 \\
0.591 \\
Y \\
Y\end{array}$ & $\begin{array}{c}7,063 \\
0.583 \\
\mathrm{Y} \\
\mathrm{Y}\end{array}$ & $\begin{array}{l}7,063 \\
0.587 \\
\mathrm{Y} \\
\mathrm{Y}\end{array}$ & $\begin{array}{c}7,063 \\
0.472 \\
Y \\
Y\end{array}$ & $\begin{array}{l}7,063 \\
0.534 \\
\mathrm{Y} \\
\mathrm{Y}\end{array}$ & $\begin{array}{l}7,063 \\
0.446 \\
\mathrm{Y} \\
\mathrm{Y}\end{array}$ \\
\hline Panel B: Triple diff & $\begin{array}{c}\text { es at compa } \\
(1) \\
\text { Total } \\
\text { departures } \\
\end{array}$ & $\begin{array}{c}\text { knowledge } \\
(2) \\
\text { Same } \\
\text { industry } \\
\end{array}$ & $\begin{array}{l}\text { ker }(\mathrm{KW}) \\
(3) \\
\text { Different } \\
\text { industry }\end{array}$ & $\begin{array}{c}(4) \\
\text { Increase } \\
\text { seniority }\end{array}$ & $\begin{array}{c}\text { (5) } \\
\text { Stay in } \\
\text { seniority }\end{array}$ & $\begin{array}{c}(6) \\
\text { Decrease } \\
\text { seniority } \\
\end{array}$ \\
\hline $\begin{array}{l}\text { Treated*Post*KW } \\
\text { Treated*Post }\end{array}$ & $\begin{array}{l}-0.540^{*} \\
(0.284) \\
-0.259 \\
(0.216)\end{array}$ & $\begin{array}{l}-0.152 \\
(0.165) \\
-0.0802 \\
(0.123)\end{array}$ & $\begin{array}{l}-0.352 \\
(0.285) \\
-0.198 \\
(0.177)\end{array}$ & $\begin{array}{c}-0.264^{* *} \\
(0.110) \\
-0.132 \\
(0.0876)\end{array}$ & $\begin{array}{c}-0.356^{* *} \\
(0.142) \\
0.149 \\
(0.123)\end{array}$ & $\begin{array}{l}0.0801 \\
(0.155) \\
-0.276^{*} \\
(0.138)\end{array}$ \\
\hline $\begin{array}{l}\text { Industry-Year FE } \\
\text { Company FE } \\
\text { State-KW FE } \\
\text { KW-Year FE } \\
\text { Observations } \\
\text { R-squared } \\
\end{array}$ & $\begin{array}{c}\mathrm{Y} \\
\mathrm{Y} \\
\mathrm{Y} \\
\mathrm{Y} \\
16,012 \\
0.322 \\
\end{array}$ & $\begin{array}{c}\mathrm{Y} \\
\mathrm{Y} \\
\mathrm{Y} \\
\mathrm{Y} \\
16,012 \\
0.311 \\
\end{array}$ & $\begin{array}{c}\mathrm{Y} \\
\mathrm{Y} \\
\mathrm{Y} \\
\mathrm{Y} \\
16,012 \\
0.304 \\
\end{array}$ & $\begin{array}{c}\mathrm{Y} \\
\mathrm{Y} \\
\mathrm{Y} \\
\mathrm{Y} \\
16,012 \\
0.256 \\
\end{array}$ & $\begin{array}{c}\mathrm{Y} \\
\mathrm{Y} \\
\mathrm{Y} \\
\mathrm{Y} \\
16,012 \\
0.293 \\
\end{array}$ & $\begin{array}{c}\mathrm{Y} \\
\mathrm{Y} \\
\mathrm{Y} \\
\mathrm{Y} \\
16,012 \\
0.222 \\
\end{array}$ \\
\hline
\end{tabular}
errors in parentheses are clustered at the state level. Industry is 4-digit NAICS. 


\section{Table 4: Departure Rate Estimates by Employee Concentration}

In this paper, the firm's main state is the state which has the most employees, according to LinkedIn. The baseline regressions do not impose a minimum fraction of employees to be in the main state. This table shows the results of the previous regressions when limiting the sample to firms with at least $20 \%$ of employees in the main state, or at least $40 \%$ of employees in the main state. For brevity, this table reports only the main coefficient of interest for each regression.

Panel A: Generalized difference-in-differences at company level. Estimates for Treated*Post.

\begin{tabular}{|c|c|c|c|c|c|c|c|}
\hline $\begin{array}{l}\text { Fraction of workers } \\
\text { in main state }\end{array}$ & $\mathrm{N}$ & $\begin{array}{c}\text { (1) } \\
\text { Total } \\
\text { departures }\end{array}$ & $\begin{array}{c}(2) \\
\text { Same } \\
\text { industry }\end{array}$ & $\begin{array}{c}(3) \\
\text { Different } \\
\text { industry }\end{array}$ & $\begin{array}{c}(4) \\
\text { Increase } \\
\text { seniority }\end{array}$ & $\begin{array}{c}(5) \\
\text { Stay in } \\
\text { seniority }\end{array}$ & $\begin{array}{c}(6) \\
\text { Decrease } \\
\text { seniority }\end{array}$ \\
\hline $0 \%+$ & 7,063 & $\begin{array}{c}-0.731^{* * *} \\
(0.248)\end{array}$ & $\begin{array}{c}-0.406^{* * *} \\
(0.143)\end{array}$ & $\begin{array}{l}-0.317 \\
(0.196)\end{array}$ & $\begin{array}{c}-0.392^{* * *} \\
(0.129)\end{array}$ & $\begin{array}{c}-0.277^{* *} \\
(0.128)\end{array}$ & $\begin{array}{r}-0.0612 \\
(0.128)\end{array}$ \\
\hline $20 \%+$ & 6,804 & $\begin{array}{c}-0.799 * * * \\
(0.259)\end{array}$ & $\begin{array}{c}-0.426 * * * \\
(0.148)\end{array}$ & $\begin{array}{l}-0.365^{*} \\
(0.209)\end{array}$ & $\begin{array}{c}-0.402^{* * *} \\
(0.133)\end{array}$ & $\begin{array}{c}-0.298^{* *} \\
(0.125)\end{array}$ & $\begin{array}{c}-0.0983 \\
(0.141)\end{array}$ \\
\hline $40 \%+$ & 5,385 & $\begin{array}{c}-0.921^{* *} \\
(0.429)\end{array}$ & $\begin{array}{c}-0.549^{* * *} \\
(0.187)\end{array}$ & $\begin{array}{l}-0.358 \\
(0.343)\end{array}$ & $\begin{array}{c}-0.494^{* * *} \\
(0.148)\end{array}$ & $\begin{array}{c}-0.393^{*} \\
(0.215)\end{array}$ & $\begin{array}{c}-0.0339 \\
(0.203)\end{array}$ \\
\hline
\end{tabular}

Panel B: Triple differences at company-knowledge worker (KW) level. Estimates for Treated*Post*KW.

\begin{tabular}{|c|c|c|c|c|c|c|c|}
\hline $\begin{array}{l}\text { Fraction of workers } \\
\text { in main state }\end{array}$ & $\mathrm{N}$ & $\begin{array}{c}(1) \\
\text { Total } \\
\text { departures }\end{array}$ & $\begin{array}{c}(2) \\
\text { Same } \\
\text { industry }\end{array}$ & $\begin{array}{c}\text { (3) } \\
\text { Different } \\
\text { industry }\end{array}$ & $\begin{array}{c}(4) \\
\text { Increase } \\
\text { seniority }\end{array}$ & $\begin{array}{c}(5) \\
\text { Stay in } \\
\text { seniority }\end{array}$ & $\begin{array}{c}(6) \\
\text { Decrease } \\
\text { seniority }\end{array}$ \\
\hline $0 \%+$ & 16,012 & $\begin{array}{l}-0.540^{*} \\
(0.284)\end{array}$ & $\begin{array}{l}-0.152 \\
(0.165)\end{array}$ & $\begin{array}{l}-0.352 \\
(0.285)\end{array}$ & $\begin{array}{c}-0.264^{* *} \\
(0.110)\end{array}$ & $\begin{array}{c}-0.356^{* *} \\
(0.142)\end{array}$ & $\begin{array}{l}0.0801 \\
(0.155)\end{array}$ \\
\hline $20 \%+$ & 15,460 & $\begin{array}{l}-0.607^{*} \\
(0.302)\end{array}$ & $\begin{array}{l}-0.170 \\
(0.167)\end{array}$ & $\begin{array}{l}-0.401 \\
(0.300)\end{array}$ & $\begin{array}{c}-0.280^{* *} \\
(0.117)\end{array}$ & $\begin{array}{c}-0.396^{* *} \\
(0.151)\end{array}$ & $\begin{array}{l}0.0681 \\
(0.156)\end{array}$ \\
\hline $40 \%+$ & 12,474 & $\begin{array}{c}-1.177^{* * *} \\
(0.434)\end{array}$ & $\begin{array}{c}-0.539 * * * \\
(0.162)\end{array}$ & $\begin{array}{l}-0.594 \\
(0.415)\end{array}$ & $\begin{array}{c}-0.387^{* *} \\
(0.168)\end{array}$ & $\begin{array}{c}-0.842^{* * *} \\
(0.200)\end{array}$ & $\begin{array}{l}0.0516 \\
(0.235)\end{array}$ \\
\hline
\end{tabular}


Table 5: NC Effect on Departures to Entrepreneurship

In Columns (1) and (2), the dependent variable is the departure rate to newly-founded companies. In Columns (3) and (4), the dependent variable is the departure rate to a founder title at a new company. In Columns (2) and (4), the sample of firms is limited to firms with at least $40 \%$ of employees in the main state. Standard errors are clustered at the state level. Industry is 4-digit NAICS.

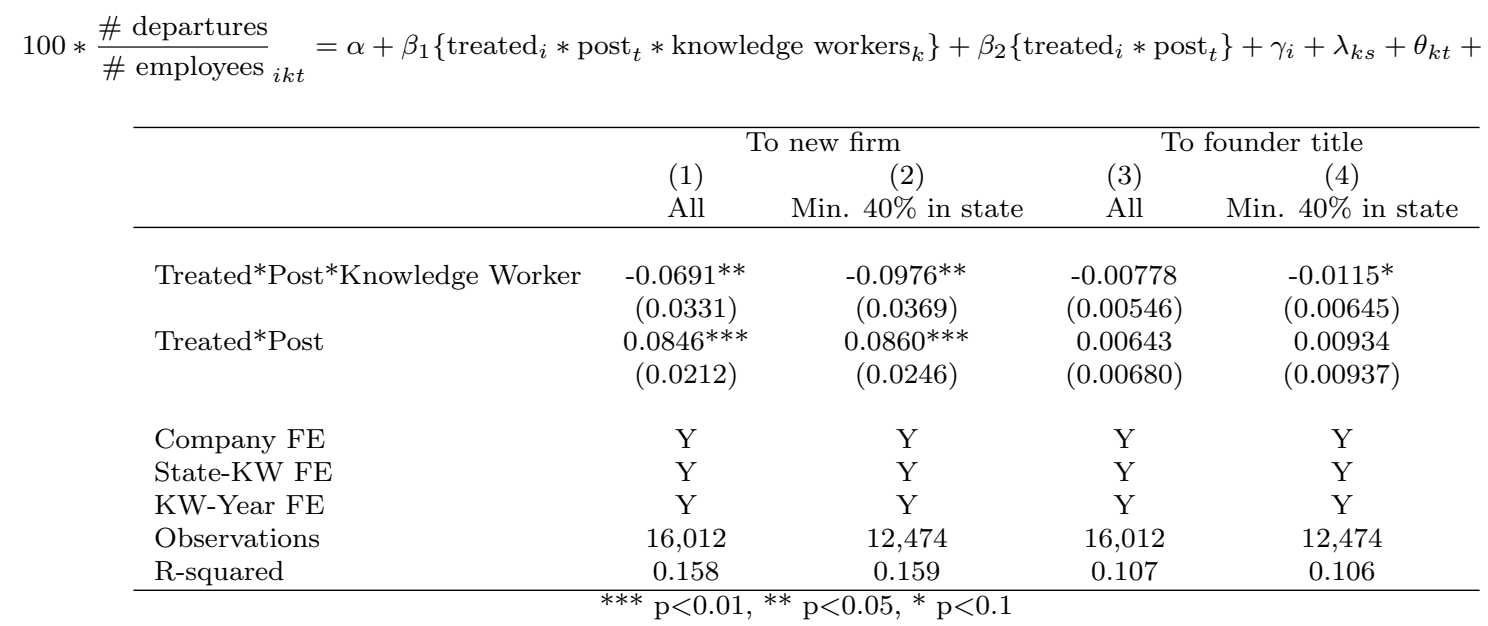




\section{Table 6: NC Effect on New Firm Entry}

The dependent variable is the number of companies founded within an industry-state-year, scaled by the state's population in millions. In Column (1), the regression is a triple differences specification with Treated*Post interacted with an indicator for Knowledge Sector (KS), which are: Technology, Professional, scientific \& technical services, and Education \& training.

$$
\frac{\text { firms founded }}{\text { million people }}_{s j t}=\alpha+\beta_{1}\left\{\operatorname{treated}_{s} * \text { post }_{t} * \text { knowledge sector }_{j}\right\}+\beta_{2}\left\{\operatorname{treated}_{s} * \operatorname{post}_{t}\right\}+\gamma_{s j}+\theta_{j t}+\epsilon_{s j t}
$$

Columns (2)-(5) break out the results in difference-in-differences specifications.

$$
\frac{\text { firms founded }}{\text { million people }}_{s j t}=\alpha+\beta\left\{\text { treated }_{s} * \text { post }_{t}\right\}+\gamma_{s j}+\theta_{j t}+\epsilon_{s j t}
$$

\begin{tabular}{|c|c|c|c|c|c|}
\hline & $\begin{array}{c}(1) \\
\text { All new firm entry }\end{array}$ & $\begin{array}{c}(2) \\
\text { Technology }\end{array}$ & $\begin{array}{c}(3) \\
\text { Prof. services }\end{array}$ & $\begin{array}{c}(4) \\
\text { Edu. \& training }\end{array}$ & $\begin{array}{c}(5) \\
\text { All other sectors }\end{array}$ \\
\hline Treated*Post*Knowledge Sectors & $\begin{array}{c}-0.0654^{* * *} \\
(0.0216)\end{array}$ & - & - & - & - \\
\hline Treated*Post & $\begin{array}{l}0.000703 \\
(0.00671)\end{array}$ & $\begin{array}{c}-0.0465^{* *} \\
(0.0172)\end{array}$ & $\begin{array}{l}-0.0800^{*} \\
(0.0434)\end{array}$ & $\begin{array}{l}-0.0809^{*} \\
(0.0432)\end{array}$ & $\begin{array}{l}-0.000703 \\
(0.00672)\end{array}$ \\
\hline Industry-Year FE & Y & Y & Y & $\mathrm{Y}$ & $\mathrm{Y}$ \\
\hline Industry-State FE & $\mathrm{Y}$ & $\mathrm{Y}$ & $\mathrm{Y}$ & $\mathrm{Y}$ & $\mathrm{Y}$ \\
\hline Observations & 31,850 & 4,753 & 6,090 & 924 & 20,083 \\
\hline R-squared & 0.773 & 0.824 & 0.813 & 0.510 & 0.549 \\
\hline
\end{tabular}

Standard errors are clustered at the state level. Industry is LinkedIn-defined industry. 


\section{Table 7: Net Investment Scaled by Capital}

The dependent variable is net investment scaled by one year-lagged net capital. In Columns (1)-(3), the regressions use the full sample of matched firms, while in Columns (4)-(6) the sample of firms is limited to firms with at least $40 \%$ of employees in the main state. In Columns (1) and (4), the regression is a difference-in-differences with all observations pooled. In Columns (2)-(3) and (5)-(6), the regression is a difference-in-difference-in-differences, or triple differences. In Columns (2) and (5), the subsample is the set of firms which employ an above-median fraction of knowledge workers. In Column (3) and (6), it is the set of firms with an above-median R\&D intensity. Standard errors in parentheses are clustered at the state level. Industry is 4-digit NAICS.

$$
\frac{I}{K}{ }_{i t}=\alpha+\beta_{1}\left\{\operatorname{treated}_{i} * \text { post }_{t}\right\}+\beta_{2}\left\{\operatorname{treated}_{i} * \operatorname{post}_{t} * \text { subsample }_{i}\right\}+\gamma_{i}+\theta_{j t}+\epsilon_{i t}
$$

\begin{tabular}{|c|c|c|c|c|c|c|}
\hline & \multicolumn{3}{|c|}{ All firms } & \multicolumn{3}{|c|}{ Min. $40 \%$ in state } \\
\hline & (1) & $(2)$ & (3) & (4) & $(5)$ & (6) \\
\hline & $\mathrm{I} / \mathrm{K}$ & $\mathrm{I} / \mathrm{K}$ & $\mathrm{I} / \mathrm{K}$ & $\mathrm{I} / \mathrm{K}$ & $\mathrm{I} / \mathrm{K}$ & $\mathrm{I} / \mathrm{K}$ \\
\hline \multirow{2}{*}{ Treated*Post } & $0.0633^{* *}$ & 0.0147 & 0.0256 & 0.0455 & -0.0117 & -0.0325 \\
\hline & $(0.0275)$ & $(0.0213)$ & $(0.0252)$ & $(0.0343)$ & $(0.0287)$ & $(0.0297)$ \\
\hline \multirow{2}{*}{ Treated*Post*Knowledge Firm } & & $0.0900^{* * *}$ & & & $0.109^{* *}$ & \\
\hline & & $(0.0331)$ & & & $(0.0510)$ & \\
\hline \multirow[t]{2}{*}{ Treated*Post*High R\&D Firm } & & & $0.0530^{*}$ & & & $0.113^{* *}$ \\
\hline & & & $(0.0267)$ & & & $(0.0446)$ \\
\hline Company FE & $\mathrm{Y}$ & $\mathrm{Y}$ & Y & Y & $\mathrm{Y}$ & Y \\
\hline Industry-Year FE & Y & & & Y & & \\
\hline Subsample-Industry-Year FE & & $\mathrm{Y}$ & $\mathrm{Y}$ & & $\mathrm{Y}$ & Y \\
\hline Observations & 4,656 & 4,459 & 4,442 & 3,587 & 3,395 & 3,402 \\
\hline R-squared & 0.569 & 0.594 & 0.575 & 0.572 & 0.596 & 0.578 \\
\hline
\end{tabular}




\section{Figures}

\section{Figure 1: Difference in Departure Rate by Years to Treatment}

This figure presents the coefficient estimate $\beta_{m}$ from the equation below, against years to treatment $m$. The estimate represents the difference in departure rate between the treated and control observations, before and after the change in enforcement of NCs.

$100 *{\frac{\# \text { departures }}{\# \text { employees }_{i t}}}_{i t}=\alpha+\sum_{m} \beta_{m}\left\{\right.$ treated $_{i} *$ m years to treatment $\}+\gamma_{i}+\theta_{j t}+\epsilon_{i t}$

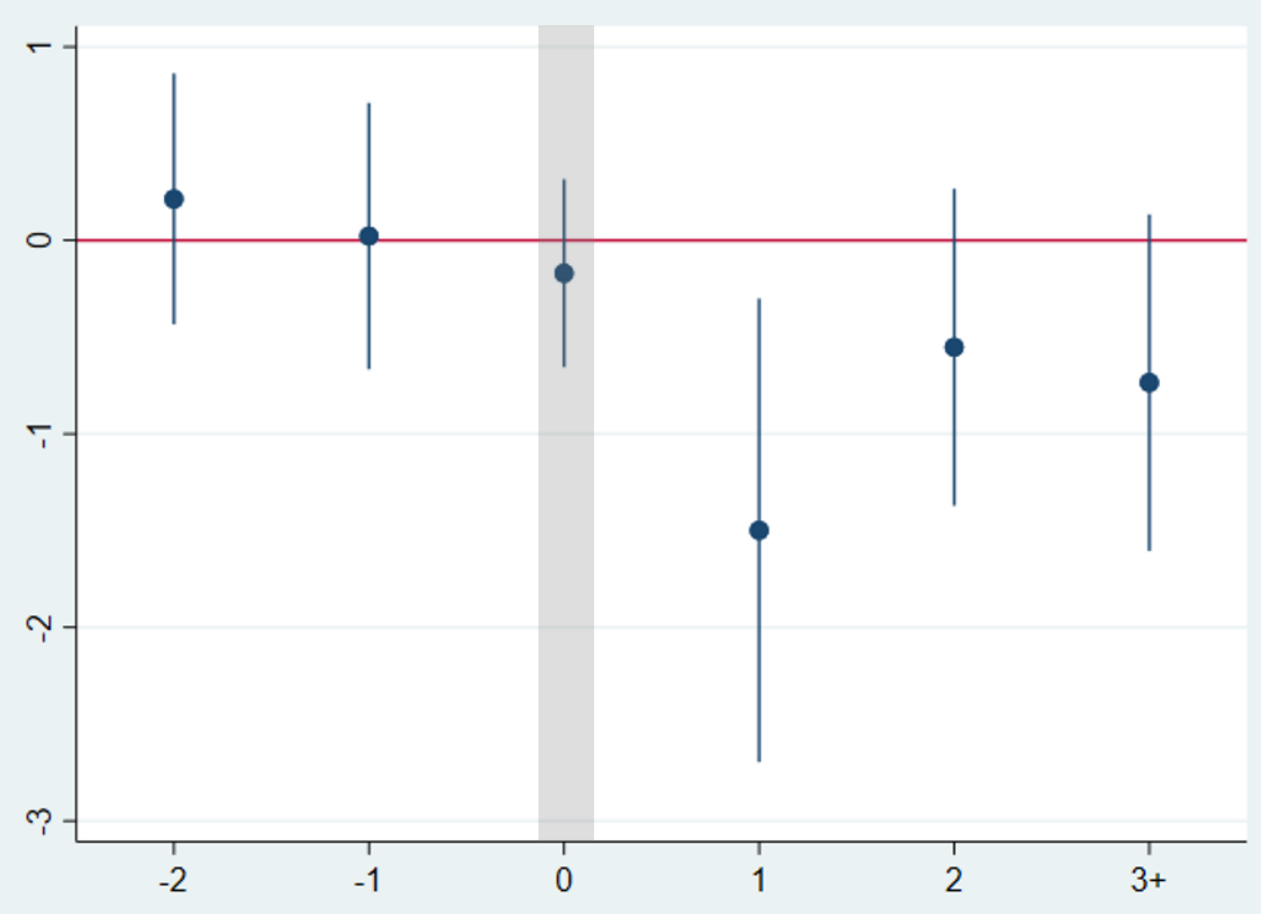




\section{Figure 2: Average State GDP/Capita (Population-Weighted)}

This figure shows average state-level GDP per capita in treated and control states, separating out the treated group into states that experience an increase in NC enforceability between 2009 and 2013, and states that experience a decrease in that time period. The figure looks very similar if the average is equal-weighted instead.

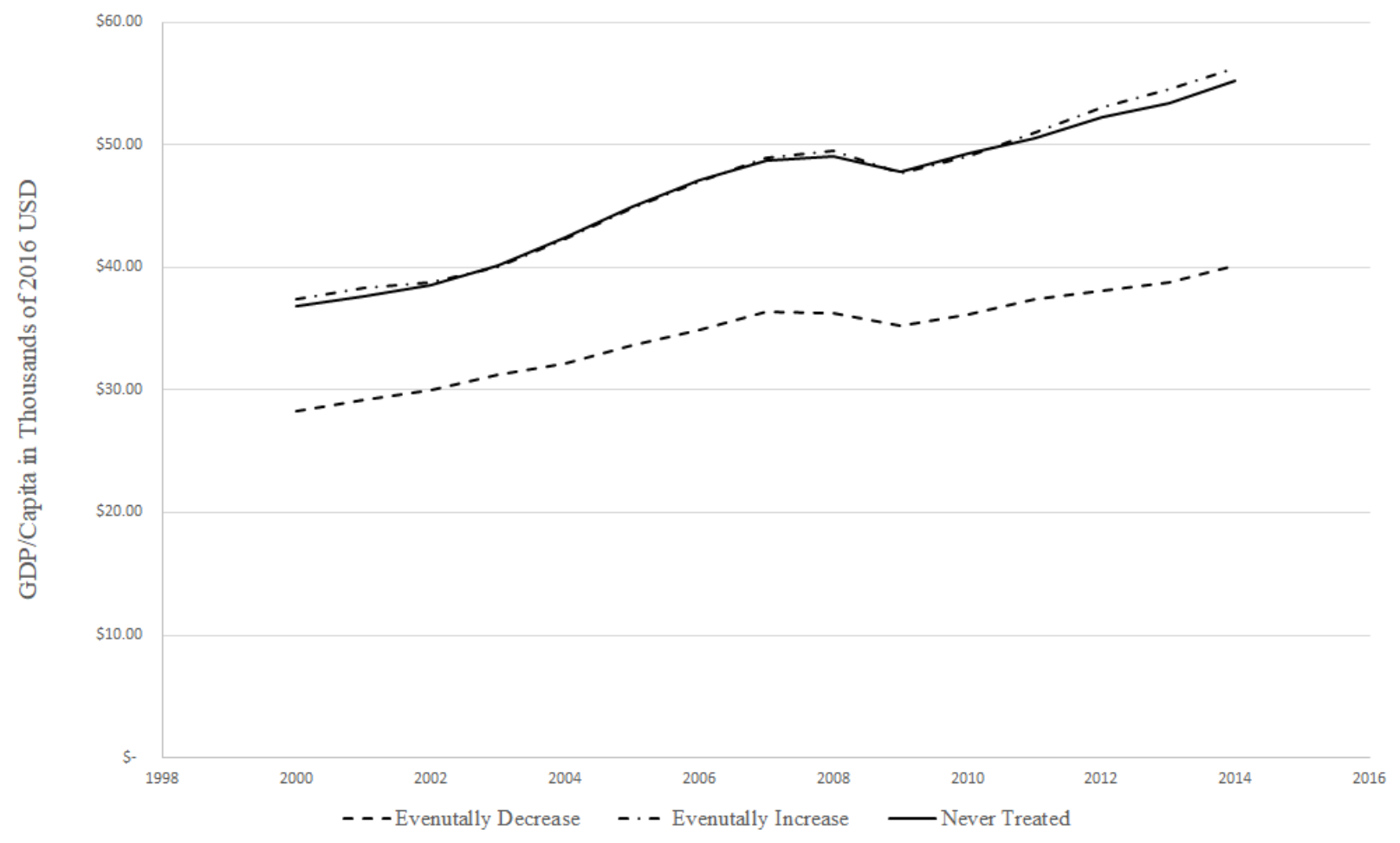




\section{A Appendix}

Table A.1: NC Enforcement Changes

\begin{tabular}{|c|c|c|c|}
\hline State & Case & $\begin{array}{l}\text { Enforcement } \\
\text { Direction }\end{array}$ & Nature of Change \\
\hline Wisconsin & $\begin{array}{l}\text { Star Direct, Inc. v. Dal Pra. } \\
(2009)\end{array}$ & $\uparrow$ & Supreme Court allows modification \\
\hline $\begin{array}{l}\text { South } \\
\text { Carolina }\end{array}$ & $\begin{array}{l}\text { Invs, Inc. v. Century Builders of } \\
\text { Piedmont, Inc. (2010) }\end{array}$ & $\downarrow$ & Supreme Court rejects modification \\
\hline Colorado & $\begin{array}{l}\text { Lucht's Concrete Pumping, Inc. } \\
\text { v. Horner (2011) }\end{array}$ & $\uparrow$ & $\begin{array}{l}\text { Supreme Court allows continued } \\
\text { consideration }\end{array}$ \\
\hline Texas & Marsh v. Cook (2011) & $\uparrow$ & $\begin{array}{l}\text { Supreme Court changes requirements } \\
\text { on business interests }\end{array}$ \\
\hline Montana & Wrigg v. Junkermier (2011) & $\downarrow$ & $\begin{array}{l}\text { Supreme Court rejects application to } \\
\text { terminated employees }\end{array}$ \\
\hline Illinois & $\begin{array}{l}\text { Fire Equipment v. Arredondo et } \\
\text { al (2011) }\end{array}$ & $\uparrow$ & $\begin{array}{l}\text { Supreme Court expands the scope of } \\
\text { interests }\end{array}$ \\
\hline Illinois & $\begin{array}{l}\text { Fifield v. Premier Dealer Services } \\
(2013)\end{array}$ & $\downarrow$ & Supreme Court restricts standards \\
\hline Virginia & $\begin{array}{l}\text { Assurance Data Inc. v. Malyevac } \\
(2013)\end{array}$ & $\uparrow$ & $\begin{array}{l}\text { Supreme Court reduces automatic } \\
\text { dismissals }\end{array}$ \\
\hline Georgia & 2011 & $\uparrow$ & Legislature allows modification \\
\hline
\end{tabular}


Table A.2: Composition of State Supreme Courts

\begin{tabular}{|c|c|c|c|}
\hline State & Composition & Appointment & $\begin{array}{r}\text { Mean Years from } \\
\text { Term End }\end{array}$ \\
\hline Colorado & $\begin{array}{l}7 \text { justices who serve } 10 \\
\text { year terms }\end{array}$ & $\begin{array}{l}\text { Uncontested retention elections after } \\
\text { initial appointment }\end{array}$ & 5.25 \\
\hline Illinois & $\begin{array}{l}7 \text { justices who serve } 10 \\
\text { year terms }\end{array}$ & $\begin{array}{l}\text { Uncontested retention elections after } \\
\text { initial contested partisan election }\end{array}$ & 5.57 \\
\hline Montana & $\begin{array}{l}7 \text { justices who serve } 8 \\
\text { year terms }\end{array}$ & Nonpartisan election & 4.17 \\
\hline $\begin{array}{l}\text { South } \\
\text { Carolina }\end{array}$ & $\begin{array}{l}5 \text { justices who serve } 10 \\
\text { year terms }\end{array}$ & $\begin{array}{l}\text { Elected and re-appointed by SC General } \\
\text { Assembly }\end{array}$ & 8.00 \\
\hline Texas & $\begin{array}{l}9 \text { justices who serve } 10 \\
\text { year terms }\end{array}$ & Partisan election & 6.00 \\
\hline Virginia & $\begin{array}{l}7 \text { justices who serve } 12 \\
\text { year terms }\end{array}$ & $\begin{array}{l}\text { Elected and re-appointed by VA General } \\
\text { Assembly }\end{array}$ & 9.40 \\
\hline Wisconsin & $\begin{array}{l}7 \text { justices who serve } 10 \\
\text { year terms }\end{array}$ & Nonpartisan election & 6.57 \\
\hline
\end{tabular}

Figure A.1: Map of NC Enforcement Changes

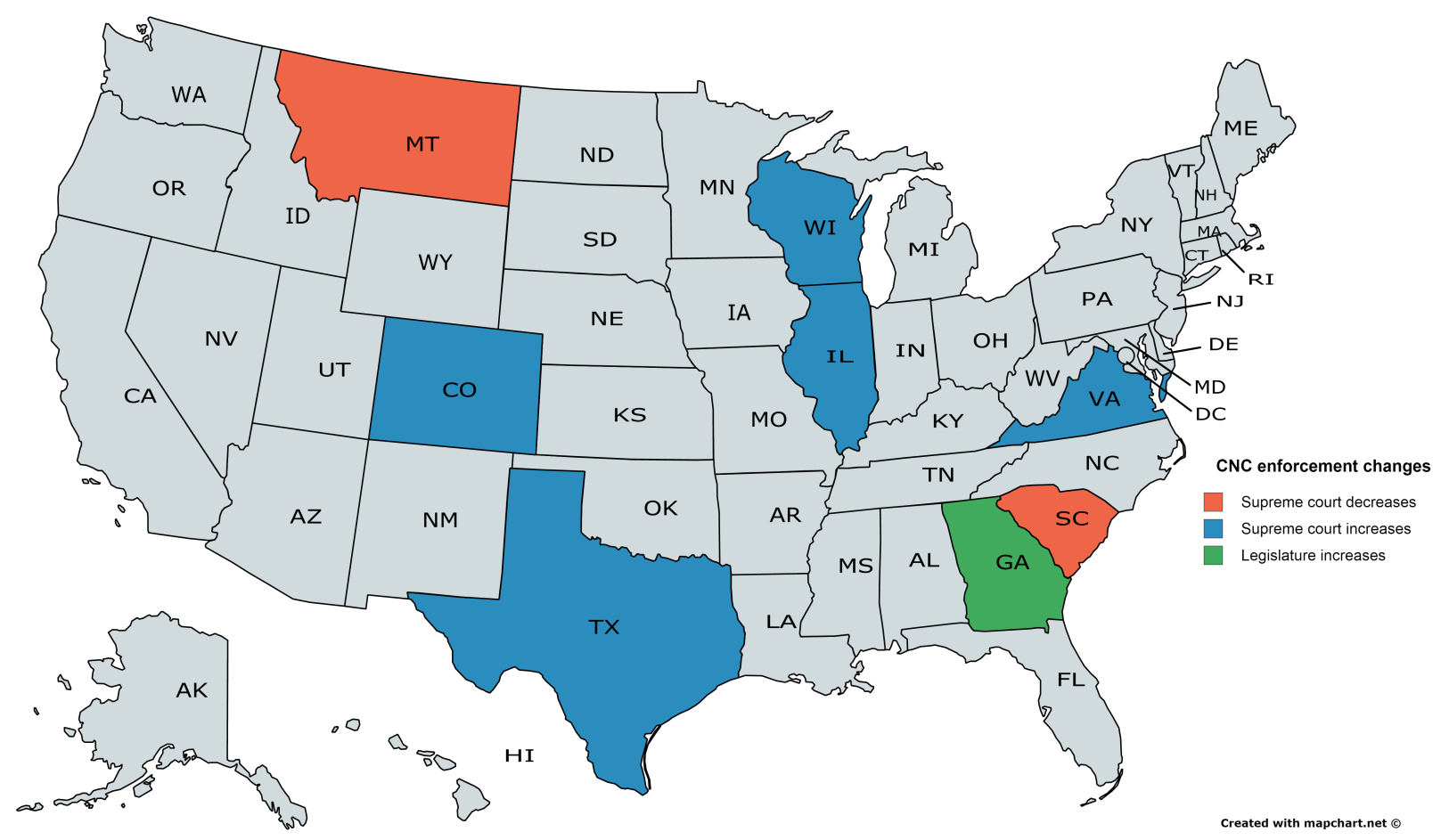




\section{Table A.3: NC Incidence and Educational Attainment}

These statistics are based on educational attainment data provided by the Bureau of Labor Statistics (BLS) and NC incidence from Starr et al (2018). To approximate years of schooling (secondary and above) for each occupation category, I assume the following mapping: less than high school: 2 years; high school or equivalent: 4 years; some college (no degree): 5 years; associate's: 6 years; bachelor's: 8 years; master's: 10 years; doctoral or professional: 12 years. The number represents an average over sub-categories of occupations, weighted by employment. Legal and community service occupations are not included in the baseline definition of knowledge worker, but results are robust to including them. LinkedIn's classification scheme provides one category for healthcare services, so both healthcare support and practitioner and technical occupations are counted as knowledge workers.

\begin{tabular}{|c|c|c|c|c|c|c|}
\hline $\mathrm{SOC}$ & Description & $\begin{array}{c}\mathrm{NC} \\
\text { incidence }\end{array}$ & $\begin{array}{l}\text { Pct bachelor's } \\
\text { or more }\end{array}$ & $\begin{array}{c}\text { Avg years of } \\
\text { schooling }\end{array}$ & $\begin{array}{c}\text { Knowledge } \\
\text { worker }\end{array}$ & $\begin{array}{c}\text { Total } 2016 \\
\text { employment }(000 \mathrm{~s}) \\
\end{array}$ \\
\hline $19-0000$ & $\begin{array}{l}\text { Life, Physical, and Social } \\
\text { Science Occupations }\end{array}$ & 0.21 & $81.0 \%$ & 8.76 & 1 & 1,300 \\
\hline $23-0000$ & Legal Occupations & 0.10 & $80.1 \%$ & 9.93 & $0^{*}$ & 1,283 \\
\hline $25-0000$ & $\begin{array}{l}\text { Education, Training, and } \\
\text { Library Occupations }\end{array}$ & 0.25 & $75.2 \%$ & 8.31 & 1 & 9,427 \\
\hline $21-0000$ & $\begin{array}{l}\text { Community and Social } \\
\text { Services Occupations }\end{array}$ & 0.15 & $70.7 \%$ & 7.89 & $0 *$ & 2,571 \\
\hline $15-0000$ & $\begin{array}{l}\text { Computer and } \\
\text { Mathematical Occupations }\end{array}$ & 0.35 & $68.8 \%$ & 7.63 & 1 & 4,419 \\
\hline $13-0000$ & $\begin{array}{l}\text { Business and Financial } \\
\text { Operations Occupations }\end{array}$ & 0.23 & $66.8 \%$ & 7.47 & 1 & 8,067 \\
\hline $17-0000$ & $\begin{array}{l}\text { Architecture and } \\
\text { Engineering Occupations }\end{array}$ & 0.36 & $64.3 \%$ & 7.45 & 1 & 2,601 \\
\hline $27-0000$ & $\begin{array}{l}\text { Arts, Design, } \\
\text { Entertainment, Sports, } \\
\text { and Media Occupations }\end{array}$ & 0.22 & $62.8 \%$ & 7.22 & 1 & 2,773 \\
\hline $29-0000$ & $\begin{array}{l}\text { Healthcare Practitioners } \\
\text { and Technical Occupations }\end{array}$ & 0.19 & $56.8 \%$ & 7.72 & 1 & 8,752 \\
\hline $11-0000$ & Management Occupations & 0.30 & $52.6 \%$ & 6.84 & 1 & 9,533 \\
\hline $41-0000$ & $\begin{array}{l}\text { Sales and Related } \\
\text { Occupations }\end{array}$ & 0.16 & $29.8 \%$ & 5.61 & 0 & 15,748 \\
\hline $33-0000$ & $\begin{array}{l}\text { Protective Service } \\
\text { Occupations }\end{array}$ & 0.19 & $26.9 \%$ & 5.73 & 0 & 3,506 \\
\hline $43-0000$ & $\begin{array}{l}\text { Office and Administrative } \\
\text { Support Occupations }\end{array}$ & 0.14 & $22.8 \%$ & 5.48 & 0 & 23,081 \\
\hline $39-0000$ & $\begin{array}{l}\text { Personal Care and Service } \\
\text { Occupations }\end{array}$ & 0.19 & $20.4 \%$ & 5.17 & 0 & 6,420 \\
\hline $31-0000$ & $\begin{array}{l}\text { Healthcare Support } \\
\text { Occupations } \\
\text { Food Preparation and }\end{array}$ & 0.26 & $12.2 \%$ & 5.03 & 1 & 4,316 \\
\hline $35-0000$ & $\begin{array}{l}\text { Serving Related } \\
\text { Occupations } \\
\text { Transportation and }\end{array}$ & 0.11 & $10.5 \%$ & 4.45 & 0 & 13,206 \\
\hline $53-0000$ & $\begin{array}{l}\text { Material Moving } \\
\text { Occupations }\end{array}$ & 0.12 & $9.0 \%$ & 4.41 & 0 & 10,274 \\
\hline 49-0000 & $\begin{array}{l}\text { Installation, Maintenance, } \\
\text { and Repair Occupations }\end{array}$ & 0.18 & $8.3 \%$ & 4.64 & 0 & 5,905 \\
\hline $51-0000$ & Production Occupations & 0.16 & $8.2 \%$ & 4.34 & 0 & 9,357 \\
\hline $45-0000$ & $\begin{array}{l}\text { Farming, Fishing, and } \\
\text { Forestry Occupations } \\
\text { Building and Grounds }\end{array}$ & 0.06 & $7.1 \%$ & 3.47 & 0 & 1,060 \\
\hline $37-0000$ & $\begin{array}{l}\text { Cleaning and Maintenance } \\
\text { Occupations }\end{array}$ & 0.11 & $6.9 \%$ & 3.98 & 0 & 5,654 \\
\hline $47-0000$ & $\begin{array}{l}\text { Construction and } \\
\text { Extraction Occupations }\end{array}$ & 0.12 & $6.4 \%$ & 4.12 & 0 & 6,812 \\
\hline
\end{tabular}


Figure A.2: Trade Secret and NC Litigation from Beck, Reed \& Riden, LLC

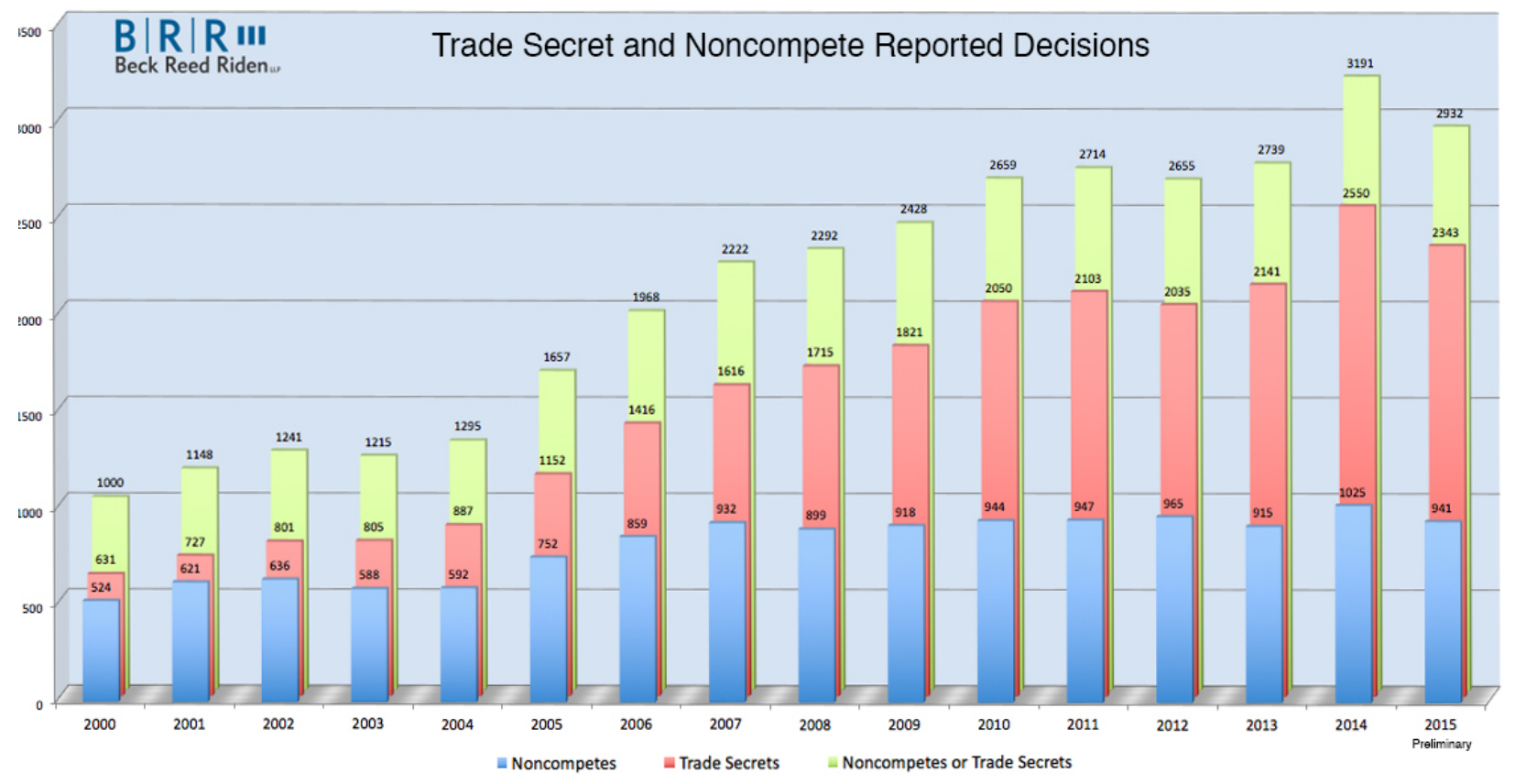

Source: Beck, Reed \& Riden, LLC, Jan. 112016 
Figure A.3: LinkedIn Coverage by Sector

This figure presents an estimated coverage rate for firms in my LinkedIn-Compustat merged sample. I divide my sample firms by Global Industrial Classification (GIC) sector, and take the total count of individuals employed in each sector according to LinkedIn in 2014, divided by the count of employees from Compustat in 2014.

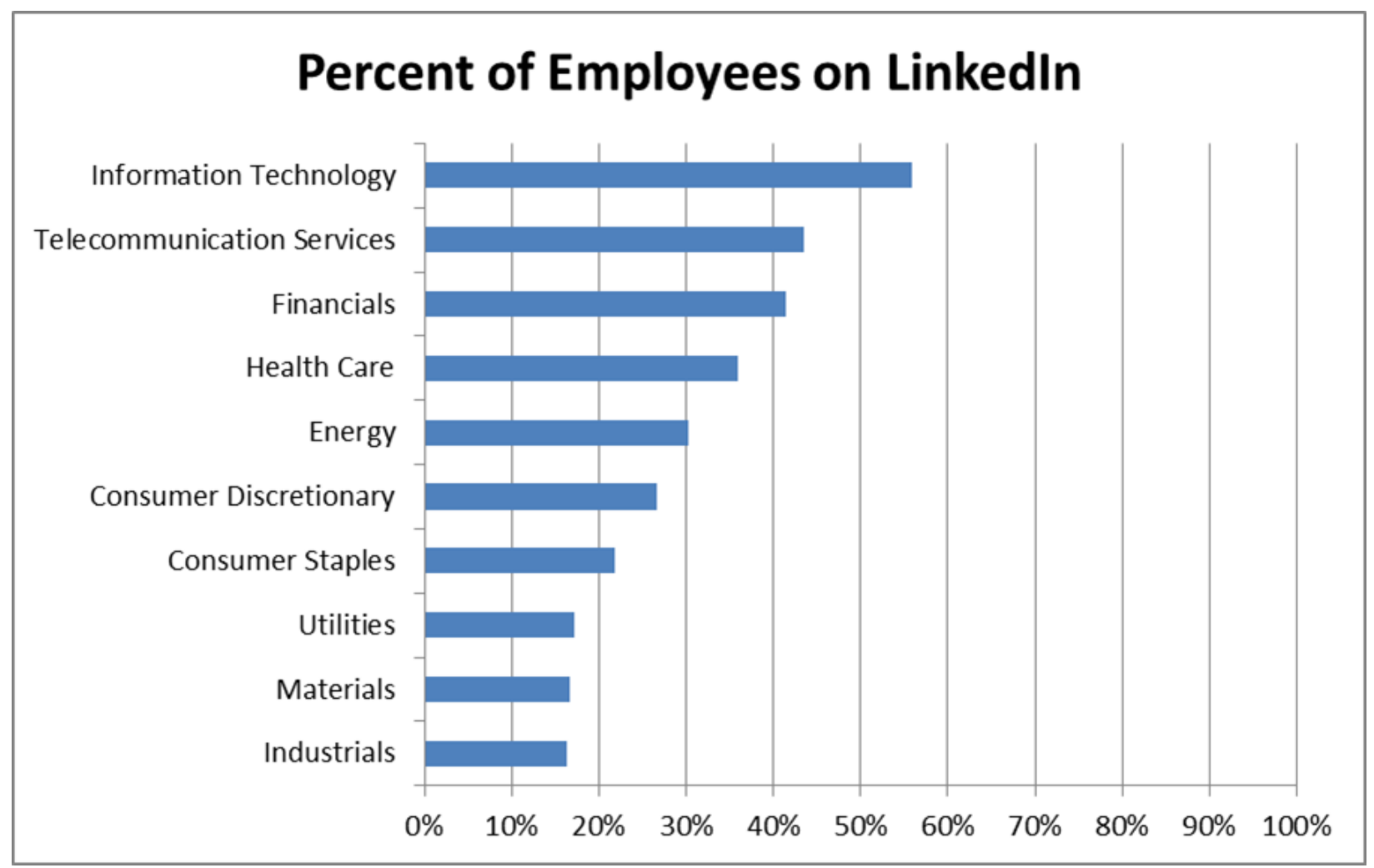


Figure A.4: Incidence of NCs by Occupation from Starr et al. (2018)

This figure comes from Starr et al. (2018). In this paper, I consider knowledge workers to be those in the right-most occupations, starting from Life, Physical, Social Sciences.

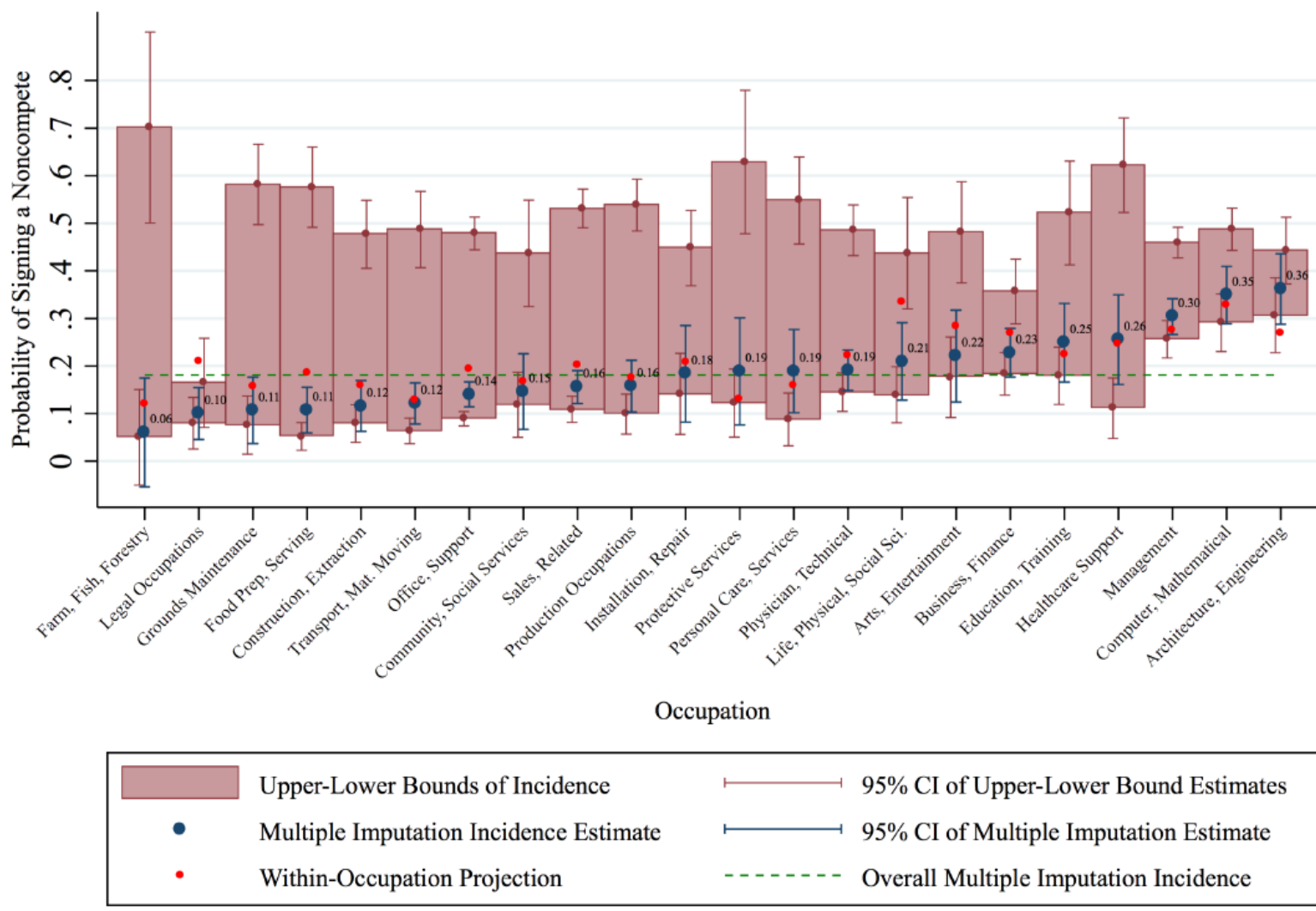

The upper-lower bounds of the incidence of noncompetes assume that those who don't know if they have signed a noncompete did and did not sign, respectively. The projections refer to within-occupation average of the projected proportion of noncompete signers. 


\section{Figure A.5: Difference in New Firm Entry by Years to Treatment}

This figure presents the coefficient estimate $\beta_{m}$ from the equation below, against years to treatment $m$. The estimate represents the difference in entry rate between the treated and control observations, before and after the change in enforcement of NCs. The first three panels present the results from the regression in each of the sectors that make up "knowledge sectors," while the last panel shows the results from the regression for all other sectors.

$$
\frac{\# \text { new firms }}{\text { population }}_{i t}=\alpha+\sum_{m} \beta_{m}\left\{\text { treated }_{i} * \text { m years to treatment }\right\}+\gamma_{i}+\theta_{j t}+\epsilon_{i t}
$$
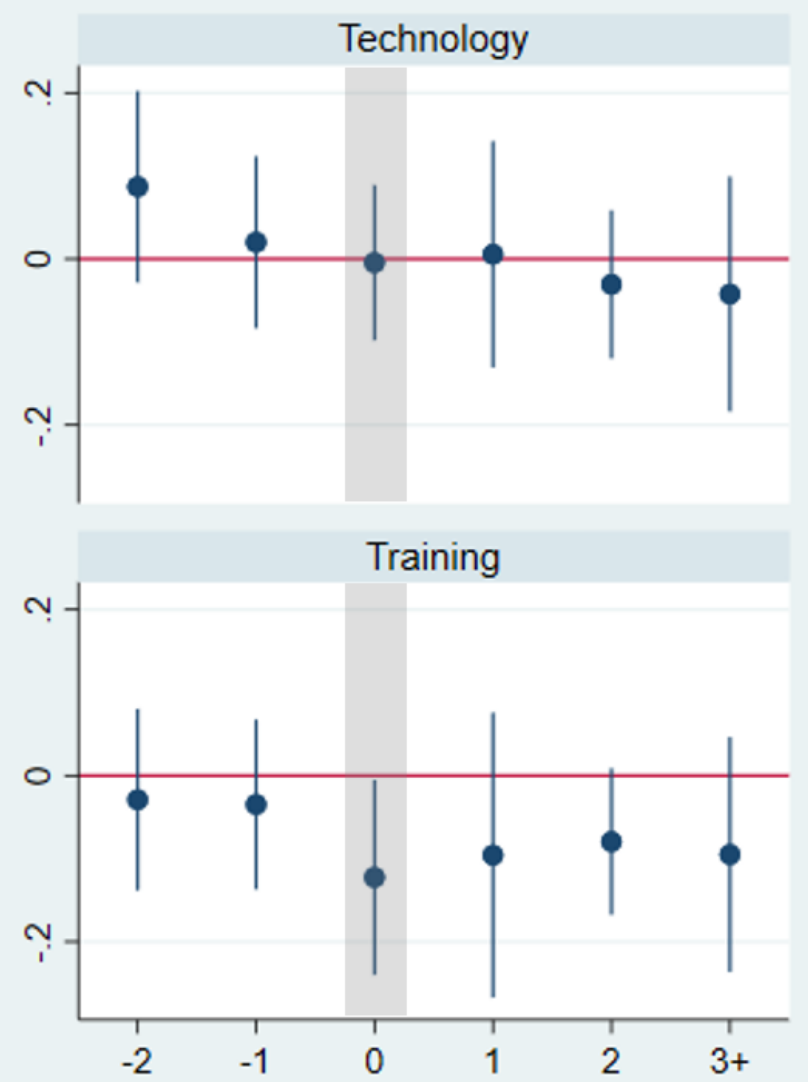

\section{Professional Services}

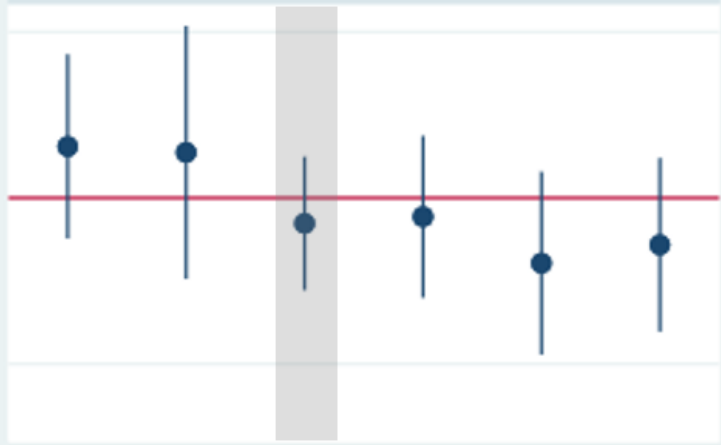

All Other Sectors

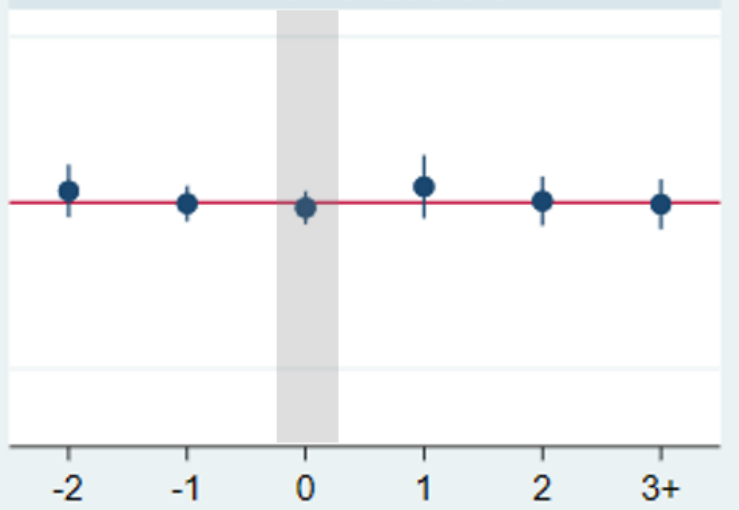




\section{Figure A.6: Difference in Investment Rate by Years to Treatment}

This figure presents the coefficient estimate $\beta_{m}$ from the equation below, against years to treatment $m$. The estimate represents the difference in investment rate between the treated and control observations, before and after the change in enforcement of NCs. Knowledge Intensive Firms are firms with a higher than median fraction of knowledge workers.(Knowledge worker occupations are arts \& design, business development, consulting, education, engineering, entrepreneurship, finance, information technology, media \& communication, operations, product management, program \& project management, and research.) R\&D Intensive Firms are firms with a higher than median fraction of R\&D to assets. These two samples are not mutually exclusive. Other Firms are firms that are neither Knowledge Intensive nor R\&D Intensive.

$$
\frac{I}{K}_{i t}=\alpha+\sum_{m} \beta_{m}\left\{\operatorname{treated}_{i} * \mathrm{~m} \text { years to treatment }\right\}+\gamma_{i}+\theta_{j t}+\epsilon_{i t}
$$
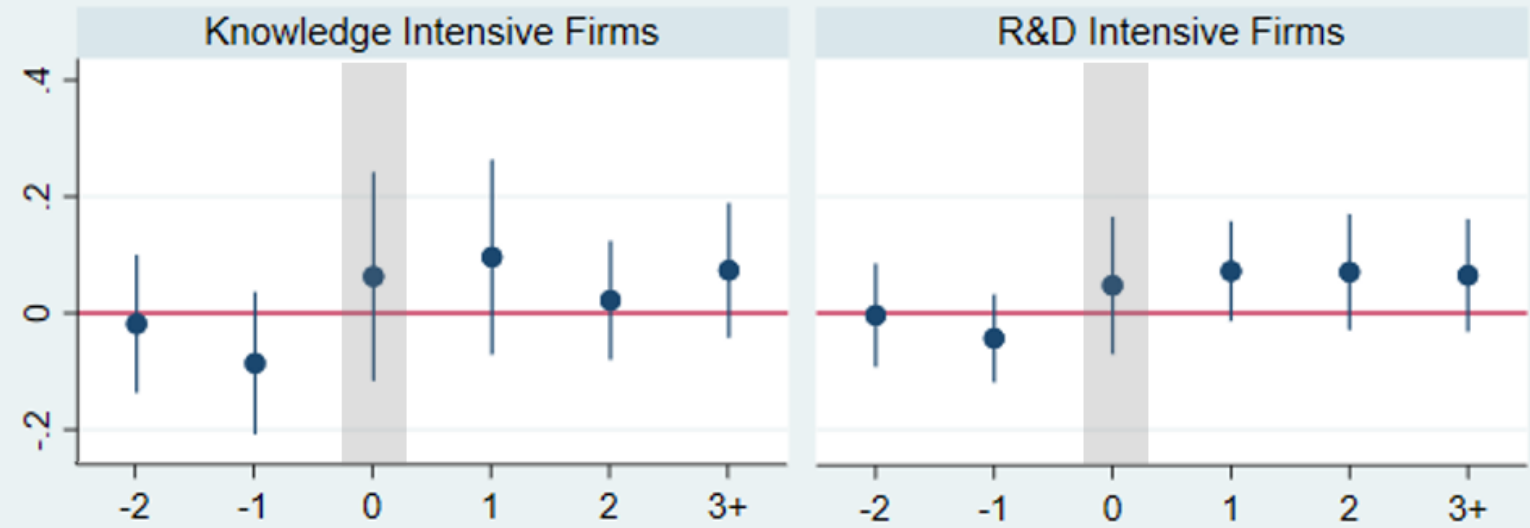

\section{Other Firms}

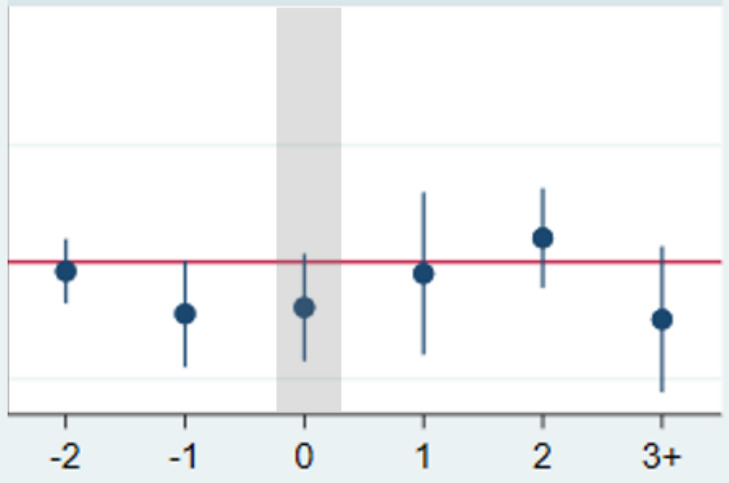

